WACŁAW SERUGA*

\section{Miejsce zamieszkania człowieka w środowisku miejskim}

\section{Man's place of residence in the urban environment}

\section{Streszczenie}

Niniejszy artykuł został poświęcony zagadnieniom związanym z miejscem zamieszkania człowieka w środowisku miejskim miejskich nadrzędną rolę pełnią miejs rozwiazania funkcjonalno-przestrzenne mieszkań / domów w powiązaniu z otoczeniem natury i architektury.

\section{Abstract}

This article has been devoted to matters associated with man's place of residence in the urban environment. In currently designed urban spaces, places assigned for human housing play a dominant role. They are characterised by assets associated with natural and architectural surroundings.

Slowa kluczowe: miejsce zamieszkania czlowieka, srodowisko miejskie, mieszzanie, dom
Keywords: man's place of residence, urban environment, apartment, house

\section{WPROWADZENIE}

Dom jako miejsce zamieszkania człowieka zwykle kojarzy się z miejskim życiem człowieka na ziemi w różnorodnych przestrzeniach społecznych i publicznych, a także kontekstach kulturowych, przestrzennych, przyrodniczych innych zachodzacych w relacjach funkcjonalno-przestrzennych z otoczeniem.

Dom jako miejsce do życia rodzin, jednostek lub całych spoteczności implikuje różnorodność rozwizzań funkcjos. tonicznych bądź układów urbanistycznych.

Zagadnieniom zwiazzanym z miejscem zamieszkania człowieka w środowisku miejskim został poświęcony niniejszy artykut.

KSZTALTOWANIE WSPÓtCZESNYCH PRZESTRZENI MIEJSKICH

reacje funkcjonalno-przestrzenne współczesnych przestrzeni miejskich zostały przedstawione $w$ różnych aspektach związanych z miejscem zamieszkania człowie$k a$, powiązane $z$ elementami natury; wody i zieleni oraz wszechstronnych powiązań w relacji człowiek - mieszkanie - otoczenie.

Poniżej zostały zaprezentowane trzy odmienne projekty architektoniczno - urbanistyczne zlokalizowane $\mathrm{w}$ róż nych przestrzeniach miejskich; społecznych, publicznych oraz rekreacyjnych o znacznych walorach krajobrazo-

\section{INTRODUCTION}

The house, understood as man's place of residence, is associated with a city-based lifestyle on Earth, in various social and public spaces, as well as in cultural spatial and natural contexts, in addition to other functional and spatial relations with the surroundings. The house, as a place of the residence of families, infunctional and spatial solutions, as well as the forms of apartments, architectural complexes or urban layouts.

This article has been devoted to matters associated with man's place of residence in the urban environment.

SHAPING CONTEMPORARY URBAN SPACES Functional and spatial designs of contemporary uraspects associated with man's place of residence, linked with elements of nature: water and greenery, as well as all other types of linkages in man-dwelling-surroundings relations.

Below is a presentation of three different architectural and urban designs, for sites in different types of urban spaces: social, public and recreational ones, each with significant landscape qualities. They feature attractive architectural designs associated with the urban context. dividuals or entire communities, implies a diversity of ban spaces have been presented in their various wych. Pokazują atrakcyjne kreacje architektoniczne zwiazane z kontekstem miejskim.

Esperymentalno-proekologiczny zespor zabudowy mieszkaniowej w Rzeszowie ${ }^{1}$ Projekt 2018 [ P.1 - P. 6 ] Praca dotyczy współczesnego proekologicznego zespołu wielorodzinnej zabudowy mieszkaniowej w Rzeszowie zlokalizowanego $\mathrm{w}$ pobliżu centrum miast pomiędzy aleją Majora Wacława Kopisto od strony północno zachodniej, ulicą Podwisłocza od strony północno wschodniej oraz rzeką Wisłoką. Od strony południowo wschodniej sasiaduje $z$ terenami zalesionymi.

Celem było stworzenie założenia architektoniczno-urbanistycznego zintegrowanego $z$ istniejącym środowiskiem przyrodniczym, a w szczególności z zielenią i z rzeka oraz zaprojektowanie optymalnej formy architektonicznej w celu uzyskania maksymalnego oświetlenia mieszkań i wnetrz urbanistycznych naturalnym świattem słonecznym oraz pozyskania znaczacej ilości energii słonecznej. Została przeprowadzon szczegótowa wszechstronna analiza stanu istniejacego, ukszaltowani terenu, walów przyrodniczych, rozwiazzań komunikacyjnch pioszch i kotowych etc oraz wązan koj zabudowy wśród której należy wyróż Coḱćlowa 25 kondygnacyjego wiezowca (realiza 2018/2019); osiedle apartamenty zamkowe - ośmiopie2018/2019); osiedle apara me zamkowe - osmiopięw 2017); oz Region an Ce (inwestycja zakończon-

W wyniku przeprowadzonych analiz oraz przyjętych załozeń funkcjonalno-przestrzennych opartych na idei zrównoważonego rozwoju, uzyskano bardzo atrakcyjny $i$ indywidualny, a zarazem oryginalny proekologiczny zespó mieszkaniowy o wielkości 345 mieszkań; 85 pokoi hotelowych; 34 pomieszczenia usługowe, handlowe i gastronomiczne; całkowita ilość pomieszczeń 1628; powierzchni oceanarium $895 \mathrm{~m}^{2}$, powierzchnia tarasów 4686 m2. Catkowita powierzchnia $51981 \mathrm{~m}^{2}$

Kreacja funkcjonalno-przestrzenna proekologicznego zespołu mieszkalno-usługowego stanowi poprzez zagospodarowanie calej powierzchni biologicznie czynnej oraz tarasów i dachów budynków zielenią oraz powiązanie funkcjonalne z rzeką Wisłoką decyduje o jedności architektury z naturą. Teren osiedla poprzez usytuowanie garazy pod budynkami został uwolniony od ruchu kołowego, a w centralnej przestzeni spolecznej zalożenia architekoniczno-urbanistycznego rola ruchu pieszego jest dominująca. Tarasowo- schodkowa forma architektoniczn budynkow mieszkalnych o organicznych ksztaltach jest wynikiem analizy nasionecznienia i zacienienia mieszkań. Układ funkcjonalny zespołu zabudowy mieszkaniowej w poziomie -1 obejmuje trzy strefy; garaże, oceanarium oraz część z pomieszczeniami gospodarczymi. Parter zawiera strefę usług, handlu, gastronomii i biur z salą konferencyjna. Kondygnacje od 1 do 4 zajmuje strefa mieszkaniowa. Kondygnacje 5 i 6 to strefy mieszkań i hotelu. Kondygnacje od 7 do $11 \mathrm{w}$ budynku A zawierają pomieszczenia hotelowe.
Experimental pro-environmental housing development complex in Rzeszów' Designed in 2018 [ $P$. - P. 6 ]

The work presents a contemporary pro-environmental complex of multi-family residential buildings in Rzeszow, located near the city centre, between Majora Waclawa Kopisto Avenue from the northwest, Podwistocza Street from the north-east and the Wistoka River. From the south-east, it borders o a forested area.

Its goal was to create an architectural and urban complex that would be integrated with the exist ing natural environment, particularly with greenery and the nearby river, and to design an optimal architectural form so as to ensure the maximum natural insolation of its apartments and urban interiors, and to generate a considerable amount of solar ensite. A detalled and broad analysis of the existing ste was pelformed, including the shape of its terculion solutions, culdings, which include: Capital Towesurs houng but 25 storey tower builing (completed in 2018/2019): the apartamenty zamkowe hou 2tate 8 pleted in 2017); as well as the Regional Sports and Entertainment Centre.

As a result of the analyses and previously adopted Aunctional and spatial objectives based on the concept of sustainable development, a very attractive and original pro-environmental housing complex was designed, featuring 345 apartments; 85 hotel suites: 34 service, commercial and gastronomic spaces; the total number of spaces amounts to 1628 ; the oceanarium floor area is $895 \mathrm{~m}^{2}$, the area of the terraces is $4686 \mathrm{~m}^{2}$. The complex's total floor area is $51981 \mathrm{~m}^{2}$. The functional and spatial design of the pro-environmental mixed-use housing and service complex unifies architecture with nature through assigning its entire biologically active surface area and that of its terraces to greenery, as well as the functional linkage with the Wisloka River. The housing estate grounds, thanks to the placement of car garages under the buildings, was freed from vehicular traffic, while the central social space of the architectural and urban complex features a predominance of pedestrian trafic. The stepped architectural form of the housing buildings, featuring prominent terraces and organic insolion and shade analysis of its apartments.

The functional layout of the housing complex at level -1 includes three zones: parking garages, an oceanarium and storage and utility rooms. The ground hoors include a service, retail and gastronomy zone, as well as an office zone with a conference hall. Floors 1 to 4 include a residential zone. Floors 5 to include apartments and hotel rooms. Floors 7 to 1 Thuilding A include hotel rooms.

The social space of the courtyard features an amphitheatrically-shaped entertainment square, as well 
Na dziedzińcu w przestrzeni społecznej zlokalizowany został amfiteatralnie uksztaltowany plac widowiskowy, a także kopuła przekrywająca oceanarium (dostępne $\mathrm{n}$ poziomie -1 ). Kopuła wykonana została $z$ hartowanego szkła wzmocnionego zbrojeniem krzyżowym po zewnętrznej stronie kopuły.

Jak pisze w swojej pracy autor projektu;

....Bodźcem przewodnim do zaprojektowania formy architektonicznej była analiza słoneczna. Ką padania słońca w poszczególnych porach dnia wraz z kolejnymi piętrami rysował linie zacienienia. Kondygnacje uformowane zostały schodkowo tak, aby ilość promieni słońca wpadająych do mieszkania była jak największa. Zabieg ten przełożył się również na ilość kondygnacii Od potudniowej jest to od czterech do pieciu kondygnaci połud

Równie ważnym aspektem jak nasłonecznienie mieszkań jest zacienienie. Słońce, szczególnie w okresie letnim, jest w stanie nagrzá pomieszczenia do wysokich temperatur. Aby zapobiec przegrzaniu zastosowane zostaty wysiegniki" balkonowe. Sztuczne przedtużenie posadzek sprawito, iz promienie stoneczne zatrzymywane zostaja kondygnacii powyżzego taras. Wraz z uptywem dnia, gdy słońce schyla sie ku zachodowi, granica ta zostaje naturanie obnizon Promienie stoneczne w petni trafioja do wymaganych pomieszczén Kolejnym sposobem na

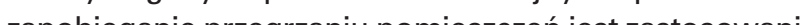
zielonych dachów. Warstwa gruntu wraz z porastającą roślinnością daja cenny cień podnosza atrakcyjność osiedla, a także zapobiegają nagrzewaniu się ostatnich kondygnacji. Efekt ten jest odwrotny zima, kiedy to dodatkowa warstwa gruntu utrzymuje odpowiednią ilość ciepła.

... Osiedle dzięki zastosowaniu "systemu schodkowego" wyposażone zostało w zielone tarasy oraz mniejsz skwery porośnięte zielenią niską, oraz wysoką. Tarasy te układają się w sposób narastający od strony południowo wschodniej, czyli zalesienia. Urbanistyka osiedla jest kontynuacją zielonego terenu. Drzewa stopniowo się przerzedzaja, jednak ich kontynuacja jest stale zachowana. Jest to dowód że architektura nie musi tylko nawiązywac do natury ale może stać się jej integralną częścią. Falist forma architektury wraz z tarasami również odwzorowuje ksztatty występujące $w$ naturze ..."

„...Pomieszczenia mieszkalne ulokowane zostały $\mathrm{w}$ tak sposób, aby mogły pozyskiwać możliwie najwięcej promieni slonecznych. Zastosowane zostaly przestrzenio tarasów oraz zielonych dachów. A ulokowanie ich od strony krajobrazowo najatrakcyjniejszej podnosi walory oraz poziom życia mieszkańców. Częsć handlowa znajduje się na parterze od stron wewnętrznych placu. Dzięki temu mieszkancy bez trudu są $\mathrm{w}$ stanie zaspokoic swoje podstawowe potrzeby materialne $\mathrm{W}$ obrębie osiedla. Podobnie jest w przypadku usług. Pomieszczenia biurowe znajdują się na terenie najbardziej odsuniętym od centrum osiedla, sale konferencyjne zostały usytuowane od strony zalesienia..." [1]

Prezentowany projekt eksperymentalno-proekologicznego zespołu zabudowy mieszkaniowej posiada as the dome covering the oceanarium (available on . pered glass with a cross reinforcement on the outer side of the dome.

The author of the project wrote the following: ...The overarching stimulus for designing the architectural form of the complex was the insolation analysis. The incidence angle of the sun during the various times of day, along with each floor, plotted the shade lines. The storeys were formed in a stepped manner so as to receive the maximum possible amount sunlight. This measure was also carried over to the number of storeys. From the south, there are be tween four and five storeys..." [1]

Shade is an aspect that is equally important to insolation. The sun, particularly during summer, is capable of significantly increasing the temperature of interiors. In order to prevent overheating, balcony "extenders" were used. Artificially extending the floor made it possible to stop sunlight at the level of the terrace above. As the day passes, when the sun sets in the west, this border becomes naturally lowered. The sun's rays fully enter the proper spaces. Another method of preventing interior overheating is to employ green roofs. A layer of soil, along with the plant that grow on it, provide precious shade, improving the attractiveness of the housing complex, in addition to protecting the uppermost floors from overheating During winter the effect is reversed, as the additiona ". .... housing estate was equipped with green terraces and tall sreery. and tall greenery. These terraces are laid out from the southeast, from the side of the forested area. The urthe green area. Trees gradually become less densety place but their continution is mains denseproof that architecture must not on but can also beco an integral part of it. The undulating form of the architecture, along with its terase, also follows the shapes that are present in neture.". " Residential spaces were placed in such a way as to receive the gretest wount of sunlight. Green as to es were implemented on the terraces and roftops. Their plimplement the side that is the most attractive in terms of the landscape significantly improves the qualities of the complex as well as the comfot of living of its residents. The commercial section is located on the ground floor from the interial section is the square Residents will be able to satisfy their basic material needs within the housing estate. The matter is similar in the case of services. Office spaces were placed in the area located at the greatest distance away from the centre of the estate, with conference halls placed from the side of the forested area " " [1] atrakcyjnie ksztaltowaną spoleczną przestrzeń miejska o silnym zwiazku mieszkan ze środowiskiem przyrodn czym, a szczególnie z otaczającą zielenią oraz rzeką Wsłoką. Całość założenia architektoniczno-urbanistycznego posiada komplet podstawowych usług, handlu, gastronomii, oświaty biur etc. Stwarza także optymaln warunki dla wypoczynku w pieszych przestrzeniach rekreacyjnych.

Ekologiczna architektura z rozległymi tarasami-ogrodami integralnie powiązana z mieszkaniami stwarza optymalne warunki jako miejsce do zamieszkania. Projekt posiad również znaczne walory przestrzenne i plastyczne.

\section{Budynek mieszkalno-biurowy przy stacji metra Ketten-} bruckengasse w Wiedniu² Projekt 2018 [P7 - P.12]

Projekt dotyczy budynku mieszkalno-biurowego zlokalizowanego w Wiedniu przy stacii metra Ketteno zlokalzowase przy starym korycie kanału rzecznego Wienfluss

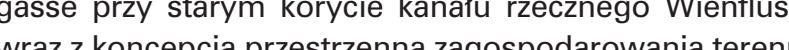
przylegiacego bezpośrednio do stacii. Przedmiotowy przylegajaco bezposred io do spedi. Predmiotowy hiej Reche Wienzile, od strony pótnocno zachodie Linke Wienzeile i od strony wschodnio północnej Kettenbruckengasse.

Objęty projektem obszar istniejącej tkanki miejskiej posiada określoną oryginalną przestrzeń $i$ historie związaną z miejskim kontekstem przestrzennym, funkcjonalnym i kulturowym. Dotyczy to najstarszej staci wiedeńskiego metra na linii U4. Budynek stacji metra jest autorstwa Otto Wagnera. Omawiany teren w XIX XX wieku stanowił plac handlowy, położony w miejscu historycznego kanału rzecznego Wienfluss, na tórym od lipca 1977 roku odbywa sie „pchli" targ $\mathrm{Na}$ schmarkt w każdą sobotę przez cały rok. Plac pełni też obecnie funkcję parkingu

W ramach rehabilitacji przestrzeni $w$ sąsiedztwie stacj metra projekt zawiera:

- wprowadzenie płaszczyzny wody do kompozycji urbanistycznej poprzez odkrycie kanału rzeki Wien

- wprowadzenie zieleni izolacyjnej, która ma tworzyć jakość rekreacji w środowisku wodno-zielonym,

- wprowadzenie kładki i ciągu pieszo-rowerowego przy kanale rzeki Wien (korekta przebiegu trasy rowerowej),

- wprowadzenie dodatkowej kładki pieszej zawieszone nad taflą wody kanału w postaci pochylni łączącej plac z kawiarnią,

kształtowanie środowiska życia człowieka na zasadach związku z przyrodą, stworzenie rekreacji nad woda $w$ mieście,

- zagospodarowanie placu z historyczną funkcją Flohmarktu (poszanowanie tradycji miejsca)

architekturę budynku integralnie związaną z zielenia i słońcem,

- architekturę budynku spełniającą standardy budynków zrównoważonych,

- architekturę budynku nawiązującą skalą do zabudowy otoczenia. [5] attractively-shaped social urban space with a strong ronment, particularly with the surrounding greenery and the Wistoka River. The entirety of the architectural and urban complex sports a full set of essential services, commerce, gastronomy, education, offices, etc. It also provides optimal conditions for rest in pedestrian recreational spaces.

Eco-friendly architecture, with extensive garden terraces that is integrally tied with the apartments, credesign also features high spatial and visual qualities.

Mixed-use residential and office building near the Kettenbruckengasse underground station in Vienna Designed in 2018 [P.7 - P.12]

The design features a mixed-use residential and office building located in Vienna near the Kettenbruckengasse underground railway station, near the old Wienfluss canal riverbed, along with a proposal of the spatial development of the area immediately adjacent to the station. The site in question is delimited by the following streets: Rechte Wienzeile from the south-east, Linke Wienzeile from the north-west Kettenbruckengasse from the east and the north.

The area of existing urban tissue covered by the design possesses a distinct, original space and a history associated with its spatial, functional and culUu line context. This applies to the oldest of Vienna's U4 line underground raliway stations. The building was designed by Otto Wagner. During the nineteenth and twentieth century, the site was a market square, used to flow, and where the Naschmark fluer canal used to How, and where the Naschmarkt flea market has been organised on a weekly basis every Saturing lot.

The design features the following elements meant to rehabilitate the space in the station's neighbourhood:

- the introduction of water surfaces to the urban composition by uncovering the Wien River canal,

the firtuction of buffer greenery, which is mean greenery-rich environment,

the introduction of a footbridge and a pedestrian and bicycle path sequence near the Wien River can (correction of the bicycle path course),

- the introduction of an additional footbridge suspended over the surface of the canal in the form of a ramp connecting the square with a coffee shop, - shaping the environment of human life in accordance with the principle of a relationship with nature, facilitating waterside recreation in the city,

- development of the square with the historical Flohmarkt function (respect for the tradition of the place) -architecture that is integrally tied with greenery and the sun 
Zaprojektowany budynek mieszkalno-biurowy podzielony został na cztery strefy:

częsc podziemną stanowiącą parking podziemny (6 kondygnacji) z mechanicznym systemem transportu na 80 miejsc postojowych oraz pomieszczenia infrastruktury technicznej, a także na poz. -1 pomieszczenia na wózki i rowery,

- część nadziemną mieszkalną obejmującą cztery piętra, - część nadziemną biurową,

- część rekreacyjną (taras) na dachu budynku. Na tarasie umieszczono basen (max gł $1.30 \mathrm{~m}$ ) oraz 4 jacuzzi, a także przewidziano rozmieszczenie różnych gatunków zielen w donicach.

Obsługa komunikacyjna budynku została zapewniona od strony południowej poprzez ulice Rechte Wienzeile.

Część mieszkalną tworzą mieszkania dwupoziomowe dostępne z galerii. Z każdej galerii dostępnych jest 10 mieszkań. Łącznie w budynku jest 20 mieszkań dwupoziomowych. Zaprojektuna jest 20 mieszkań dwuponicowanc Zalóci $i$ pokoje dzienne i sy poloje dzien i sypialne posiadaja kom loggie bęc. kania. Mioszkania maja zapewnione dwéctonne przeprzezane. Tars maja zacy przeznaczony jest wylacznie da mieszkancow. Na kondygnacjach dostęprych z galen przy trzonie komunika-

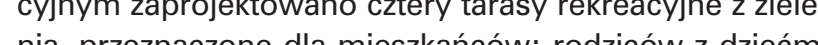
niá, przeznóczow a także osob niepelnosprawnych, będące miejscem wy poczynku i integracji mieszkańców.

Prezentowane mieszkania stwarzają optymalne miejsc zamieszkania dla rodzin oraz jednostek $w$ rehabilitowanej, atrakcyjnie ksztaltowanej pieszej przestrzeni publicz nej, w kontekście elementów przyrody; zieleni oraz rzeki Wien

Oryginalna ekologiczna kreacja współczesnej architektury budynku mieszkalno - biurowego ksztattowana jes w myśl zasad projektowania zrównoważonego.

Zostały zachowane optymalne relacje funkcjonalno przestrzenne pomiędzy dwupoziomowymi mieszkania$\mathrm{mi}$, a rekreacyjnym otoczeniem; prywatnych loggi oraz wspólnych przestrzeni rekreacyjnych usytuowanym n tarasach budynku. Płuca miasta. Eksperymentalny kompleks oczyszczania
powietrza w środowisku miejskim Kielc ${ }^{3}$ Projekt 2018 [P.13 - P.19]

Smog każdego roku zabija miliony ludzi na całym świecie a liczba ta zatrwazająco zwiększa się z roku na rok zbierając kolejne żniwo. Liderem najbardziej zanieczyszczonego powietrza na świecie od wielu lat są Chiny. W roku 2017 Kielce zostały okrzyknięte Chinami Europy za sprawa zatrważająco wysokiego stężenia zanieczyszczeń powietrza. Zachęcano aby w tym okresie mieszkańcy zrezygnowali z wychodzenia z domu, a gdy będzie to konieczne korzystali z komunikacji zbiorowej. Smog powoduje szereg schorzeń występujących we wszystkich grupach
- architecture that meets the standards of sustainable buildings,

- architecture that refers to the scale of the area's extant buildings. [ 5 ]

The residential and office building featured in the design was divided into four zones:

- an underground section, featuring an underground parking garage (6 storeys) with a mechanical transport system, with 80 parking spaces and technica infrastructure spaces, as well as spaces for strollers and bicycles on level -1 ,

- an above-grade section including four storeys,

- an above-grade office section

a recreational section (a terrace) on the building's roof. The building's terrace includes a swimming pool (max depth of $1,3 \mathrm{~m}$ ) and 4 Jacuzzi bathtubs, along with various species of potted plants. The building has access to Rechte Wienzeile street from the south.

The residential section is comprised of two-level apartments accessed from a gallery. 10 apartments can be accessed from each gallery. The building features 20 two-level apartments in total. Five types of apartments that vary in size and functional layou were designed. All of the living rooms and bedrooms have comfortable loggias that are an extension of the internal space of the apartment. The apartments can be cross-ventilated. The recreational terrace above the residential section can only be accessed by residents. The storeys accessible from the gallery near the circulation core include four recreational terraces

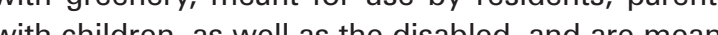
Wh children, as well as the disabled, and are meant The a place for residents to rest and integrate. The apartments create optimal places of residence The context of elements of nature, greenery and the Wien River.

The original oco-friendly contemporary architecture of The original eco-friendly contemporary architecture of 列 timal functional and spatial relationships between the two-level apartments and their recreational surroundtho of the building's terraces have been maintained. The lungs of the city. Experimental air purification complex in the urban en
signed in 2018 [P.13 - P.19] Smog kills millions of people per year all around the
world, with the number of dead frighteningly increasing from year to year. China is the global leader in ing from year to year. China is the global leader in named the China of Europe because of the terrifying concentration of air pollutants in the city. Its residents were encouraged not to leave their houses and use public transport when necessary. Smog causes wiekowych. Zanieczyszczenie powietrza wpływa negatywnie na kobiety w ciąży. Smog wpływa niekorzystnie na mózg; wywołuje stany depresyjne, problemy z koncentracja, prowadzi do udarów mózgu. Powoduje takż zawał serca, nadciśnienie tętnicze, chorobẹ niedokrwienną serca, zaburzenia rytmu serca, niewydolności serca. To tylko niektóre z listy konsekwencji zanieczyszczonego powietrza [4]

Celem pracy było stworzenie eksperymentalnego kompleksu poświęconemu szeroko rozumianej problematyce zwiazanej z oczyszczaniem powietrza w środowisku miejskim Kielc. Integralnym elementem kompleksu beda rozmieszczone $w$ strategicznych punktach miasta stacje związane z oczyszczaniem powietrza. Autorka zaproponowała 6 stacji oczyszczania powietrza w mieście; przy alei Szajnowicza-Iwanowa, przy ulicy Turystycznej, ulicy Gabrieli Zapolskiej, na, placu Wol Túcystycznej, uloy Gabrieli Zapolskiej, na placu Wolnosci, ulicy Młode oczyszczajace powietrze powstały w Holandii, w China

i w Polsce.

Projektowane założenie architektoniczno - urbanistyczne z funkcją edukacyjną i badawczą zlokalizowano przy ulicy Bernardyńskiej w okolicach słynnej Karczówki, w środowisku przyrodniczym z dużą bioróżnorodnością i pięknym widokiem na panoramę Kielc. Całe założenie ma spełniać ważną funkcję przywracania równowagi w jakości powietrza oraz nauczać i szkolić mieszkańców Kielc i wszystkich zainteresowanych. Prosta forma architektoniczna wpisuje się w istniejący krajobraz, podkreślając jego piękno.

Budynek został zaprojektowany w formie horyzontal-

nej. Bryła została podzielona na dwa poziomy, zgodnie z zastanymi różnicami wysokości. Docelowo ma stać sie integralną cześcią środowiska, w które została wpisan poprzez $\mathrm{m}$. in. rozrastanie się $\mathrm{w}$ sposób naturalny istniejących już roślin. Elewacja została wykonana z elementów prefabrykowanych, pozyskanych w wyniku recyklingu, nawiązując kolorami do naturalnych form skalnych, a duże przeszklenia odbijają otaczający krajobraz. Kompleks zawiera 4 patia w których moźna umieścić drzewa i zieleń, są one otwarte dla zwiedzających. Pod względem funkcji obiekt posiada część biurowa $z$ salami konferencyjnymi, pomieszczeniami technicznymi, socjalnymi etc. Strefa edukacyjna zawiera sale laboratoryjne, doswiadczalne oraz wykładowe, czytelnie etc. Obiekt zawiera takze sale interakcyjne dla najmłodszych, sale doświadczalne, wykładowe i laboratoria dla młodzieży i dorosłych oraz sale wystawiennicze i multimedialne. Obiekt umozzliwia aktywne spędzanie czasu, obcowanie z naturą oraz doszkalanie swoich umiejęt nosci. W nizszzej kondygnacji budynku znajdują się sale laboratoryjno-badawcze, które mają na celu udoskonalenie rozwiązań mających na celu walkę ze smogiem innymi zanieczyszczeniami środowiska. Obiekt zamyka duża aula do organizowania profesjonalnych konferencj naukowych etc. [4]

Zagospodarowanie terenu zostało urozmaicone elementami wody oraz zieleni, które zapewnią schronienie w najbardziej upalne dni. Na terenie znajdują się zbiorniki na a range of illnesses that affect all age groups. Air pollution negatively affects pregnant women. Smog negatively affects the brain, causing depression, concentration problems, and can lead to stroke. can also cause heart attacks, hypertension, coronary artery disease, heart arrhythmia and heart failure. These are just some of the elements on the long list of the consequences of air pollution [4].

The goal of the project was to design an experimental complex devoted to the broadly understood subject matter of air purification in the urban environment of Kielce. The complex's integral element are air purification stations to be placed at strategic sites throughout the city. The author proposed 6 air purfication stations: near Szajnowicza-lwanowa Street, near Turystyczna Street, on Wolosci Square, Młoda Street and Kazimierza Wielkiego Street. The first such stations have already been built in the Netherands, China and in Poland.

The architectural and urban complex that is the subject of the design, featuring an educational and research function, was placed at Bernardyńska Street, in the area of the famous Karczónka, in a natura environment characterised by high biodiversity and a beautiful view of Kielce's panorama. The complex is to fulfil the important function of restoring balance in air quality and to teach and train the residents of Kielce and all who are interested. The simple ar chitectural form blends into the existing landscape highlighting its beauty.

The building was designed to feature a horizonta form. The massing was divided into two levels, in accordance with the extant differences in terrain elevaf the is unity fow the existing phants. The facade was desiged gex cycled mor with its colors, ing a refection of the surrounding landscape. The complex includes 4 patios where tres and greenery can be placed, and which ar open to visitors. In terms of function, the building includes an office section with conference halls, technical and socia spaces, etc. The educational section includes aboratories, experimentation rooms and lecture spaces, reading room, etc. The building also includes in action spaces for children, experimental, spaces, ecture halls and laboratories for both the youth and adults, as well as exhibition and multimedia spaces. The building makes it possible to spend one's time actively, facilitates contact with nature and the improvement of one's skills. The lower storey includes laboratory and research spaces, which are meant to develop solutions to combat smog and other types of environmental pollution. The building ends with a large auditorium that can be used to organise professional academic conferences, etc. [4]

The site was enhanced through the addition of water features and greenery, which provide shelter during 
wodę opadową, która ma słuzyć pielęgnacji rosslin. Na terenie lokalizacji usytuowano również szkókkę roslin, ktore posiadają wlasciwosci mocno filtrujące powietrze. Obiek nie posiada parkingow dla samochodow prywatnych. Komunikacja zbiorowa pozwala ograniczyć ilość aut prywatnych, a co za tym idzie zniwelować zanieczyszczenie powietrza związane ze spalinami samochodowymi. Kompleks został zaprojektowany w myśl zasad projektowani zrównoważonego; posiada panele fotowoltaiczne z których pozyskiwana będzie energia etc. Przyjete założenie przestrzenne odzwierciedla dażenie do symbiozy środowiska przyrodniczego, człowieka i architektury.

Praca przedstawia rozwiazanie funkcjonalno-przestrzenne eksperymentalnego kompleksu oczyszczania powietrza wśrodowisku miejskim Kielc. Rozwiązanie architektoniczno-urbanistyczne cechuje czytelność oraz atrakcyine rozwiazanie funkcjonalne. Lapidarna architektura operujaca kromnymi środkami wyrazu, została harmonijnie wpisare w krajobrazowe ofoczenie cechuia ja silne zwiazki ze

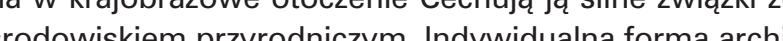
ektoniczna oraz kompozycja nawiazują do otaczajacego naturalnego środowiska miejsca.

Zdrowe powietrze stanowi warunek konieczny dla określenia optymalnego miejsca zamieszkania człowieka w środowisku miejskim.

\section{Podsumowanie}

Jak pokazały wyżej zaprezentowane przykłady kreacii architektoniczno-urbanistycznych, we współcześnie ksztaltowanych przestrzeniach miejskich szczególna, adrzędną, dominującą rolę zajmują miejsca przeznaczone do zamieszkania przez czlowieka. Dotyczą one aspektów związanych z kompozycja przestrzenną, pięknem, optymalnych rozwiązan funkcjonalno-przestzennych mieszkan wraz z otoczeniem, a także relacji z elementami natury; słoncem, zielenią, wodą etc. Istotną rolę w ksztaltowaniu mieszkania / domu jako miejsca zamieszkania człowieka w srodowisku miejsk pelnią przestrzenie wspólne; publiczne, spoleczne, kulturowe etc., o różne oli, skali i znaczeniu.

RZYPISY

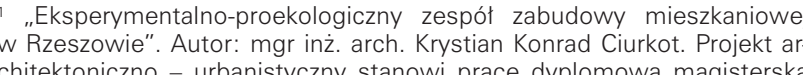
chitektoniczno - urbanistyczny stanowi prace dyplomowa magisterska orrchitektury Politechniki Ś Swiętok rzyskiej, Kierunek Architektura. Promotor pracy magisterskiej: prof. dr hab. inzi. arch. Wactaw Seruga. Praca 19 za magisterka prace dyplomowa "El

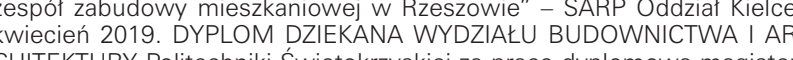

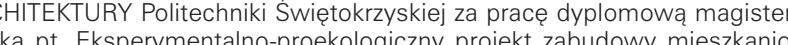
wej $w$ Rzeszowie, Kielce 2019. Materiaty źroddtowe: Archiwum Katedry
i Urbanistyki Wydziatu Budownictwa i Architektury Politechniki SwiętoI Urbanistyki Wydzial
krzyskiej w Kielcach.

„Budynek mieszkalno-biurowy przy stacii metra Kettenbruckengasse w Wiedniu". Autor: mgr inzi. arch. Monika Petecka. Projekt architektow 2018 roku na Wydziale Architektury Politechniik Krakowsskiej. Kierunek Architektura. Promotor pracy magisterskiej: prof. dr hab. inz
arch. Wactaw Seruga Materiaty zródtowe. Archivum Katedry Kstatito
wania Srodowiska Mieszkaniowego, Wydziat Architektury Politechnik Wania Srodowiska Mieszkaniowego, Wydziat Architektury Politechnik
Krakowskiej. hot days. The site includes tanks for surface runoff that filter air pollution. fertion. The building does not feature akes it possible to rivate cars. Public transport cars, which can help to alleviate the problem of air pollution caused by car engine exhaust. The complex was designed in accordance with the precepts of sustainable development; it includes photovoltaic panels meant to generate energy, etc. The spatial scheme reflects the pursuit of a symbiotic relationship betwee the natural environment, mankind and architecture. The project presents the functional and spatial solutions of an experimental air purification complex located in Kielce's urban environment. The architectural and urban design solutions are characterised sy clarity and an attractive, functional scheme. The simple an antecture, which operates using modest merreng inkas with the naturat environment. Its origing roch rounding natural environment of the place.

Healthy air is a condition that is necessy to define optimal place of ronment.

\section{Conclusions}

As the examples of architectural and urban design projects presented above have demonstrated, places of human residence play a distinct, overarching and dominant role within currently shaped urban spaces. They pertain to aspects associated with spatial composition, beauty, as well as optimal functional and spatial solutions in their apartments, along with their surroundings, as well as relationships with elements of nature: the sun, greenery, water, etc. Common spaces: public social and cultural ones, of varying role, scale and significance, play an essential role in the design of a apartment or house as a place of human residence.

ENDNOTES

".Eksperymentalno - proekologicznny zespót zabudowy mieszkanioWej w Rzeszowie". Author: mgr inz. arch. Krystian Konrad Ciurkot,
The architectural and urban design was developed as a Master's
project and defended with distinction in July 2018 at the Faculty of Civi Eng dology, Course: Architecture. Master's project supervisor: prot
dr hab. inz. arch. Wactaw Seruga. The work received the follow-
ing awards: Nomination for the 2019 Diploma Project of the Yea N ward for the Master's project „Eksperymentalno - proekologiczn
Espót zabudowy mieszkaniowej w Rzeszowie". - Kielce branch of he SARP, April 2019. Diploma of the Dean of the Faculty of Civis gy for the Master's czny zespót zabudowy mieszkaniowej w Rzeszowie", Kielce, 201 Source materials. Archive of the Chair of Resier "Budynek mieszkalno - biurooyy przy staciji metra Kettenbrucken gasse w Wiedniu". Author: $\mathrm{mgr}$ inz. arch. Monika Petecka. The ar-
chitectural and urban design was developed as a Master's proje and defended in 2018 at the Faculty of Architecture of the Cracow Universty or Tin 2018 a Dervisor: prof. dr hab. inzi. arch. Wactaw Seruga. Source material
Archive of the Chair of the Shaping of the Housing Environment. Faculty of Architecture of the Cracow University of Technology.
".Pluca miasta. Eksperymentalny kompleks oczyszczania powietrza W srodowisku miejskim Kielc". Autor: mgr inż. arch. Karolina Ewa Me
Projekt architektoniczno-urbanistyczny stanowi prace dyolomowa mat sterska obroniona z wyrózinieniem w lipcu 2018 roku na Wydziale Budow nictwwa I Architektury Politechniki I Wivetokrzyyskiej, Kierunek A Architektura
Promotor pracy magisterskiej: prof. dr hab. inz. arch. Wactaw Seruga

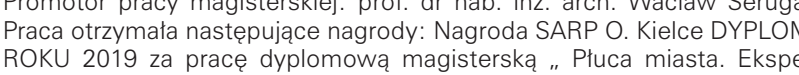
Ymentalny kompleks oczyszczania powietrrza w w środowisku miejski
Kielc", Kielce kwiecień 2019. NAGRODA PREZYDENTA MIASTA KIELCE za najepsza prace dyplomowa dotyczaca Miasta Kielce pt. Ptuca miasta
Eksperymentalny kompleks oczsyczzania powietrza w srodowisku mie skim Kielc. Kielce kwiecieñ 2019. Nominacia do konkursu DYPLOM ROK 2019 za prace dyplomowa magisterska, „Pluca miasta. Eksperymentaln

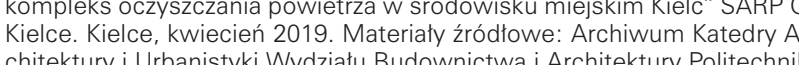

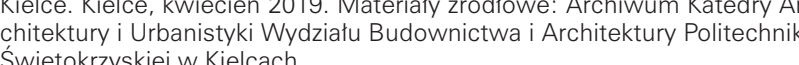

LITERATURA

1] Ciurkot K.K., Eksperymentallno-proekologiczny zespót zabudow mieszkaniowej w Rzeszowie, praca dyplomowa magisterska wykonan
na Wydziale Budownictwa i Architektury Politechniki Swietokrzyskiej Kie na Wydzias
ce 2018 r.
[2] Gehl $\mathrm{j}$.
jezyk pols

[2] Gehl I. Miasta dla Iudzi, wyd. 2010, wydawnictwo w tlumaczeniu na

ych, wyd. 1971, wydawnictwo w w tlumaczeniu na jezzk polskei RAM, Kra-

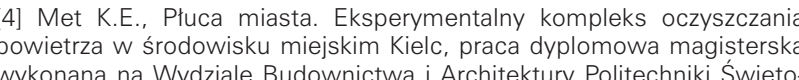
wykonana na Wydziale
krzyskie, Kielce 2018 r. bruckengasse w Wiedniu, praca dyplomowa magisterska wykonana n [6] Seruga W. Architektura kontekstu, monografia Architektura 1/2014
wyd. Politechnika Swietokrzyska. Kielce 2014. wyd. Politechnika Swiętokrzyska, Kielce 2014.
[7] Seruga W., Eksperymenty i poszukiwania w ksztattowaniu wspótczes-

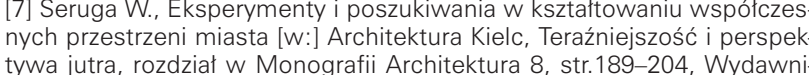
tywa jutra, rozdziat w Monografii Architektura 8, str.189-204, Wydawni-
ctwo: Politechnika Swieteokrzyska, Kielce 2019. [8] Seruga W., Kreacie architektoniczne w miejskiej przestrzeni [W:] Ar-

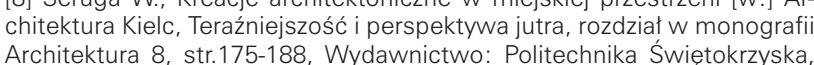

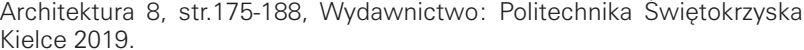
[9] Seruga W., Kreacie w przestrzeni miasta [W: Architektura kontekstu,
monografia Architektura $1 / 2014$ wyd. Politechnika Swiętokkrzyska, Kielce

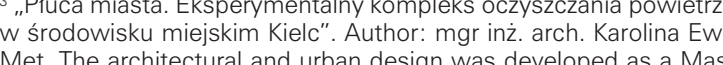
ter's project that was defended with distinction in July 2018 at the of Technology Course: Architecture. Master's project sunenis prof. dr hab. inż. arch. Wactaw Seruga. The work received the following awards: the 2019 Diploma Project of the Year Award for the czania powietrza $\mathrm{W}$ środowisku mieieskim Kielc" "- Kielce branch of
the SARP, April 2019. The Award of the President of the City of Kielce or the best diploma project concerning the City of Kielce, entitle
Pfuca miasta. Eksperymentalny kompleks oczyszczania powietra W Środowisku miejskim Kielc" Kielce, April 2019, Nomination for
the 2019 Diploma Project of the Year competition for the Master's project "Pluca miasta. Eksperymentalny kompleks oczyszzzania po-
wietrza w srodowisku miejskim Kielc"- Kielce branch of the SARP Kielce, April 2019. Source materials: Archive of the Chair of Res
tial Buildings of the Kielce University of Technology in Kielce

LITERATURE

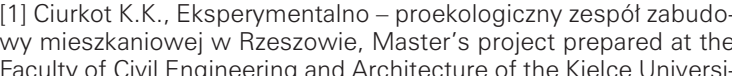
ty of Technology Kielce 2018 , 218 , [2] Gehl J., Miasta dla ludzi, publ.. 2010, published in Polish by
RAM, Kraków 2014. 3) Gehl J., Zycie miedzy budynkami. Uiytkowanie przestrzeni pub-
licznych, publ. 1971, published in Polish by RAM, Kraków 2009. 14] Met K.E., Pluca miasta. Eksperymentalny kompleks oczyszcza-
naa powietraz w srrodowisku miejskim Kielc, Master's project pre-
pared at the Faculty of Civil Engineering and Architecture of the Kelce University of Technology, Kielce 201

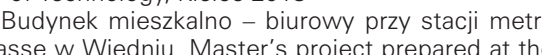
Faculty of Architecture of the Cracow University of Technology

$1 / 2014$ publ. Politechnika Swiętokrzyska, Kielce 2014 wspotczesnych przestrzeni miasta [in:] Architektura Kielc, , Teraz-

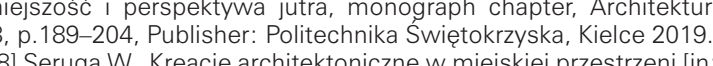
Architektura Kielc, Teraźniejszość i perspektywa jutra, monograph
chapter, Architektura 8, p.175-188, Publisher: Politechnika Świętokrzyska, Kielce 2019. [9] Seruga W. Kreacje w przestrzeni miasta [w:] Architektura kon-
tekstu, monograph Architektura 1/2014 publ. Politechnika Święto- 


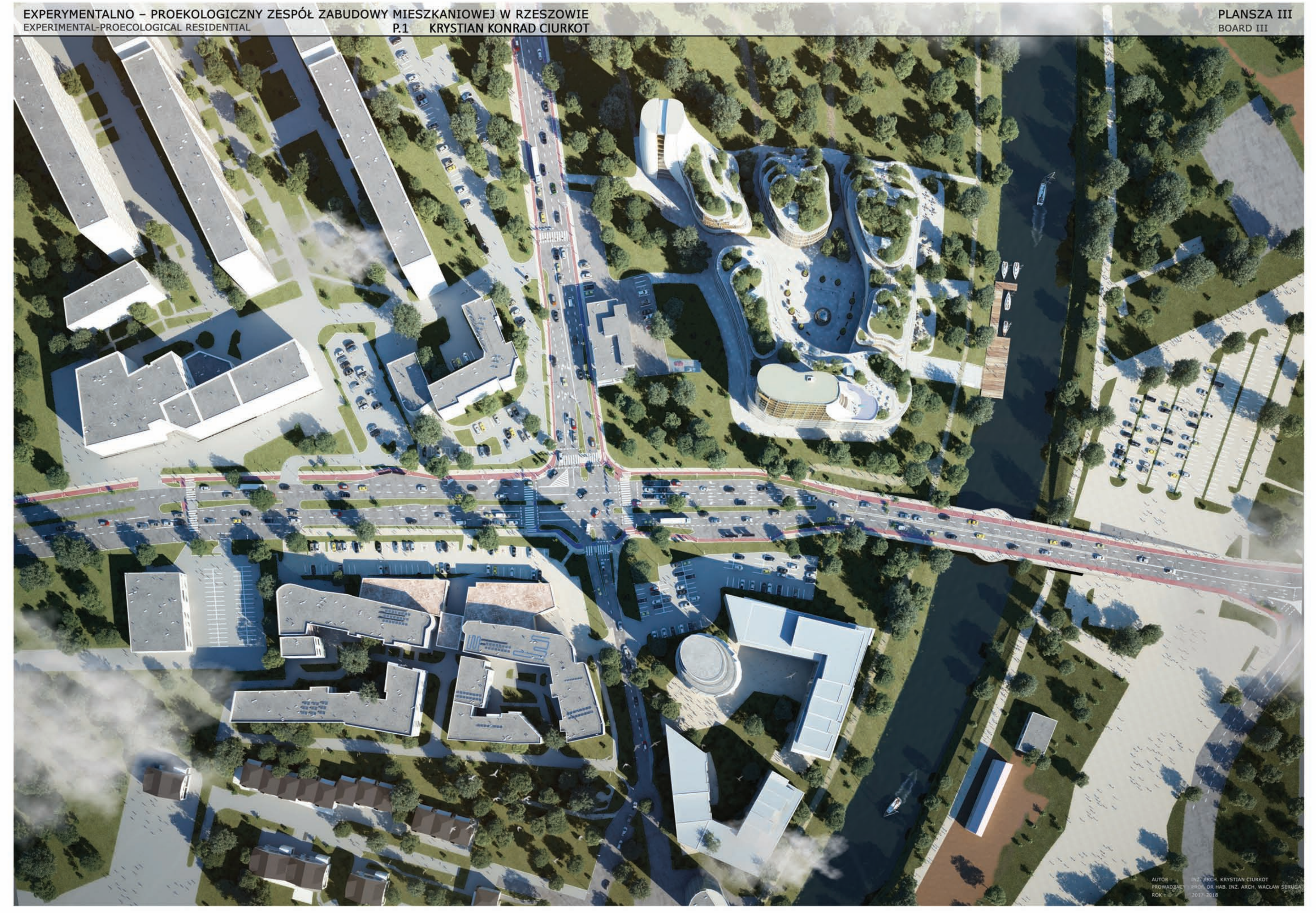




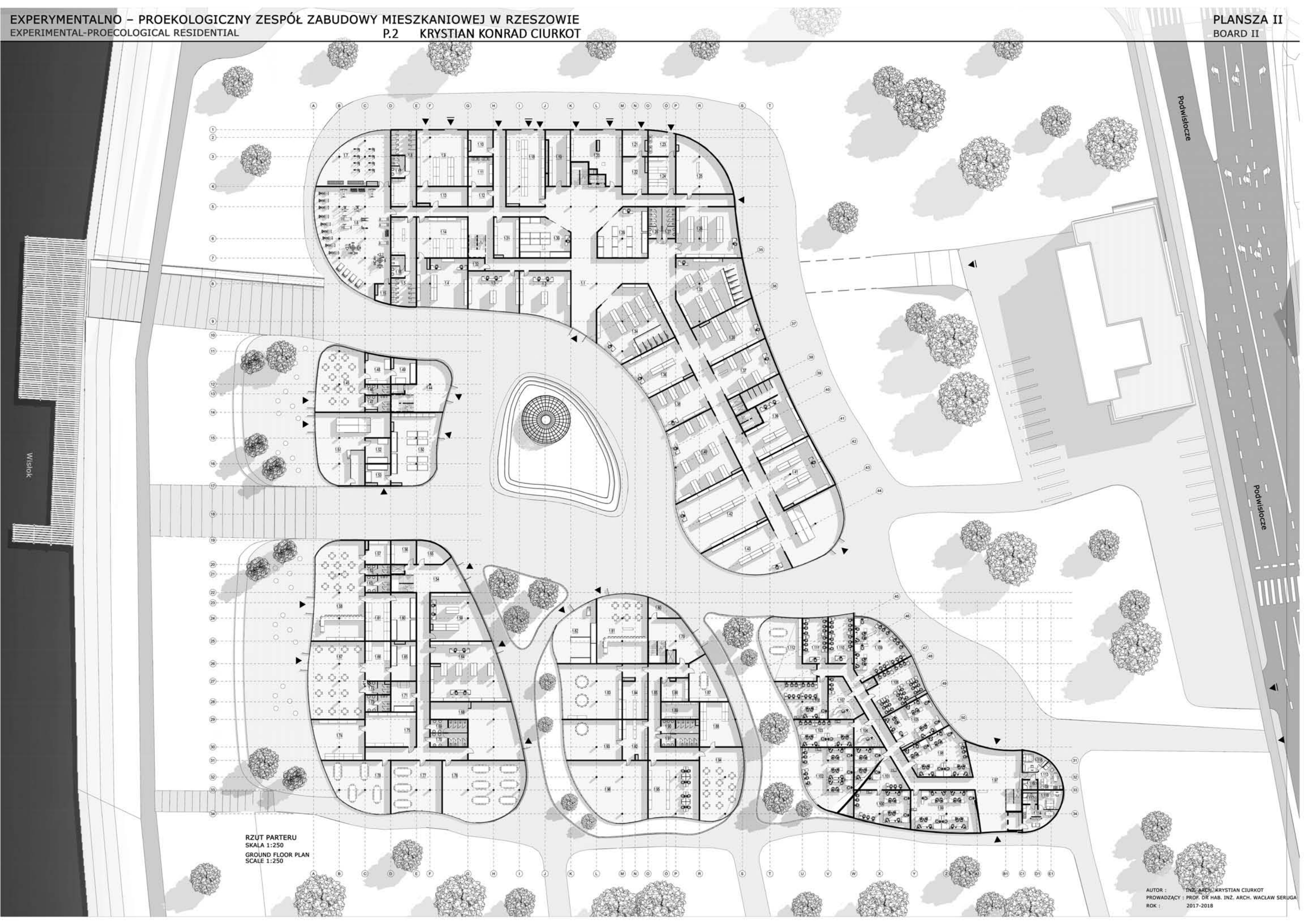




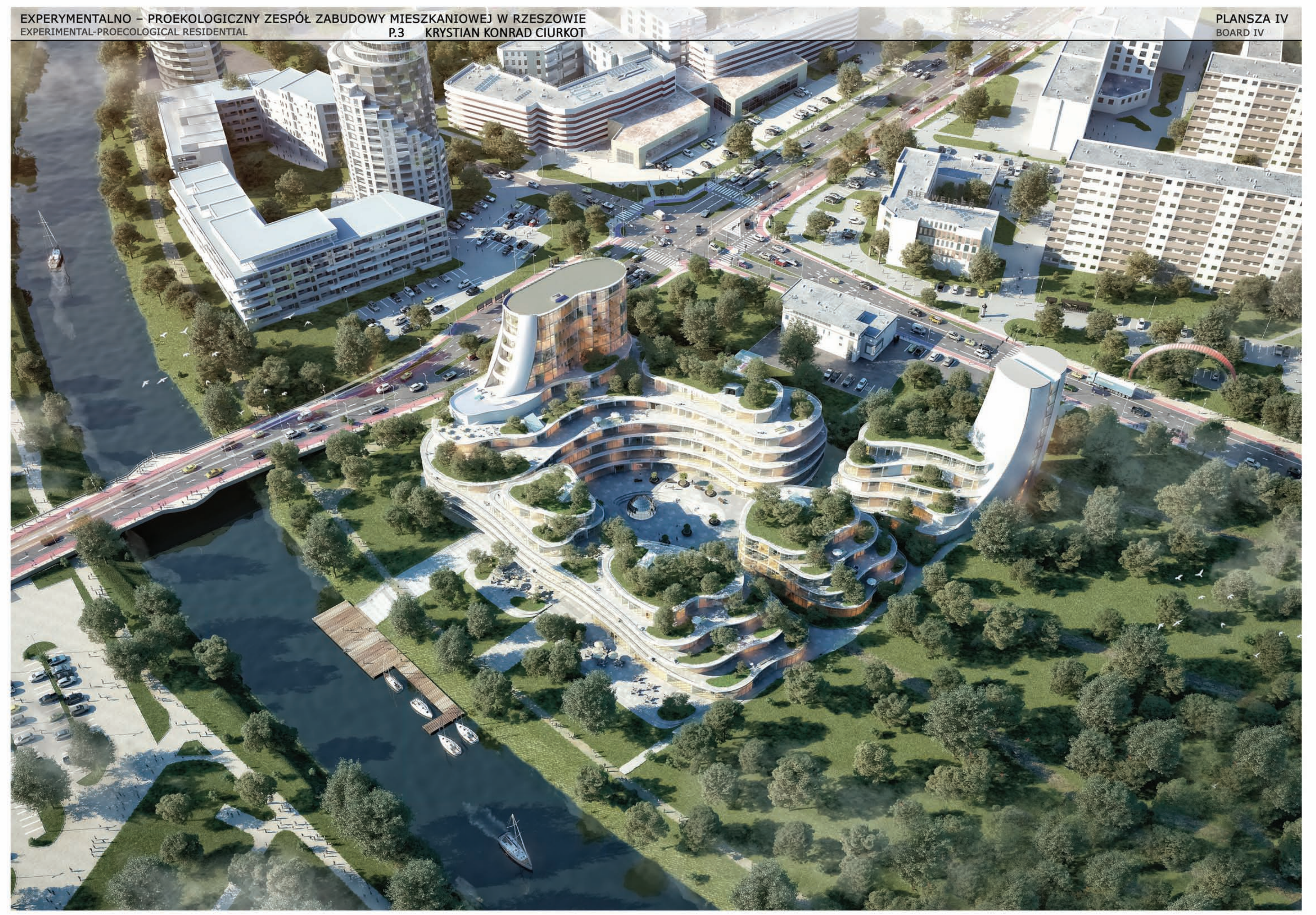




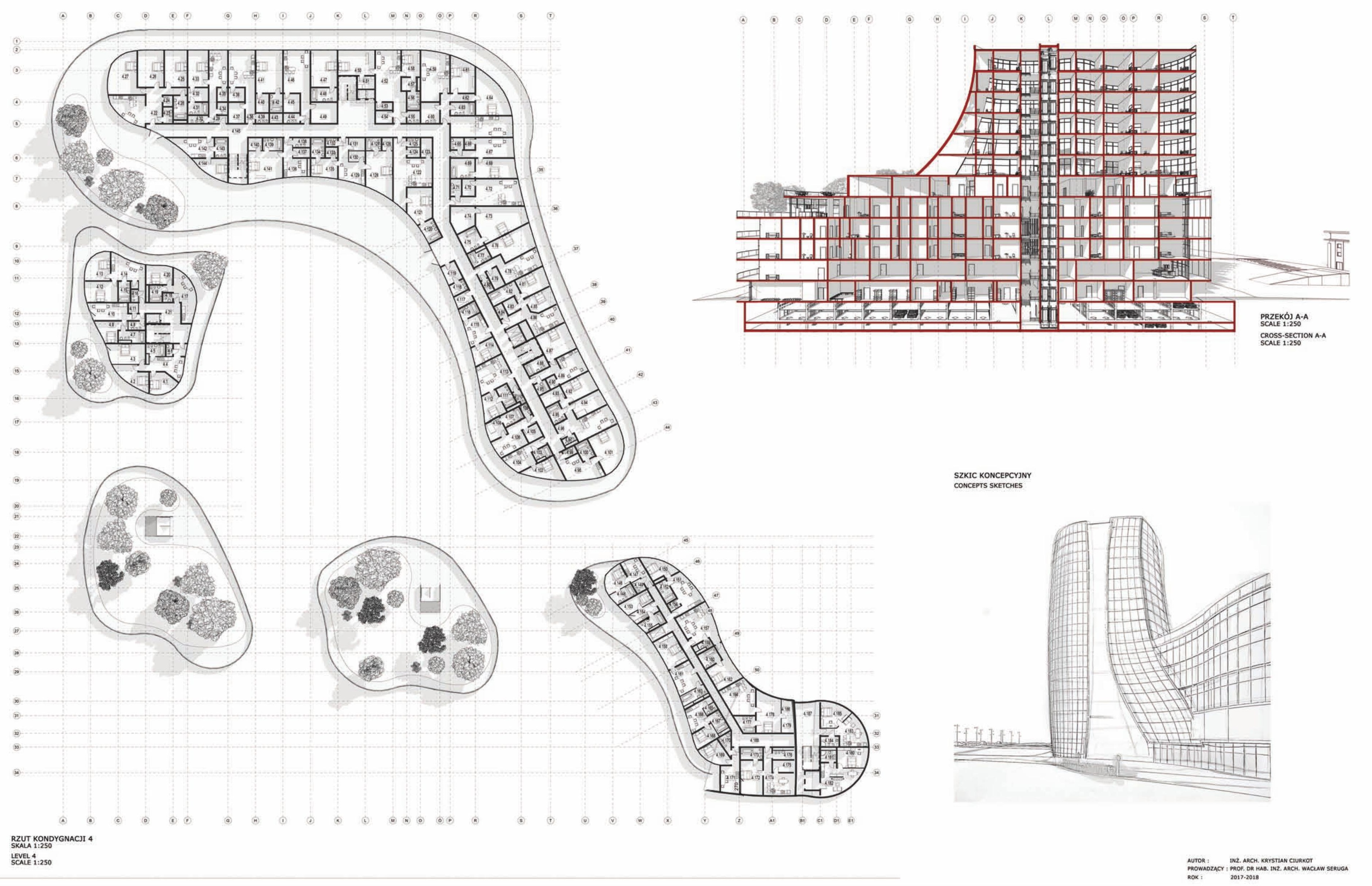




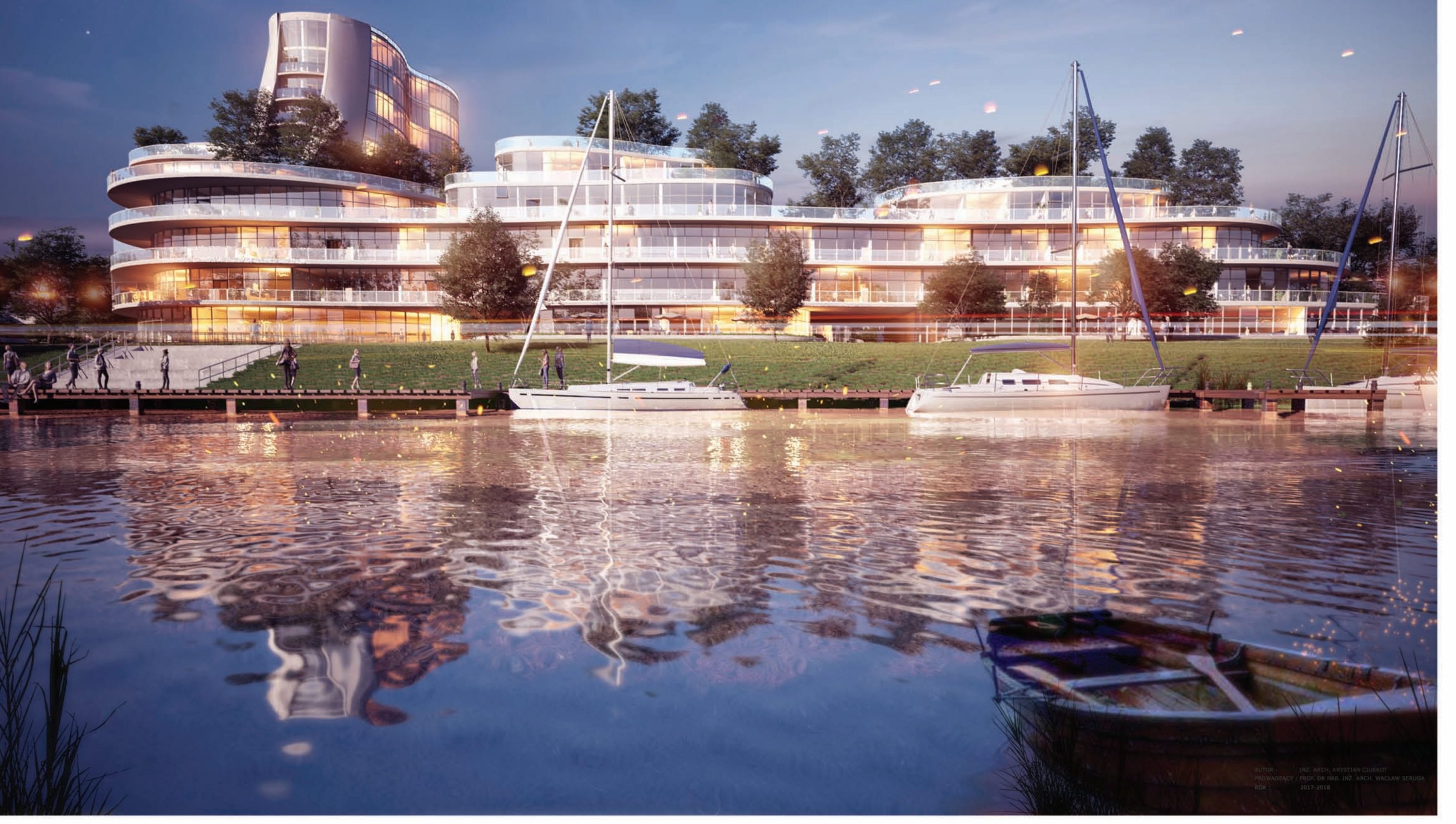




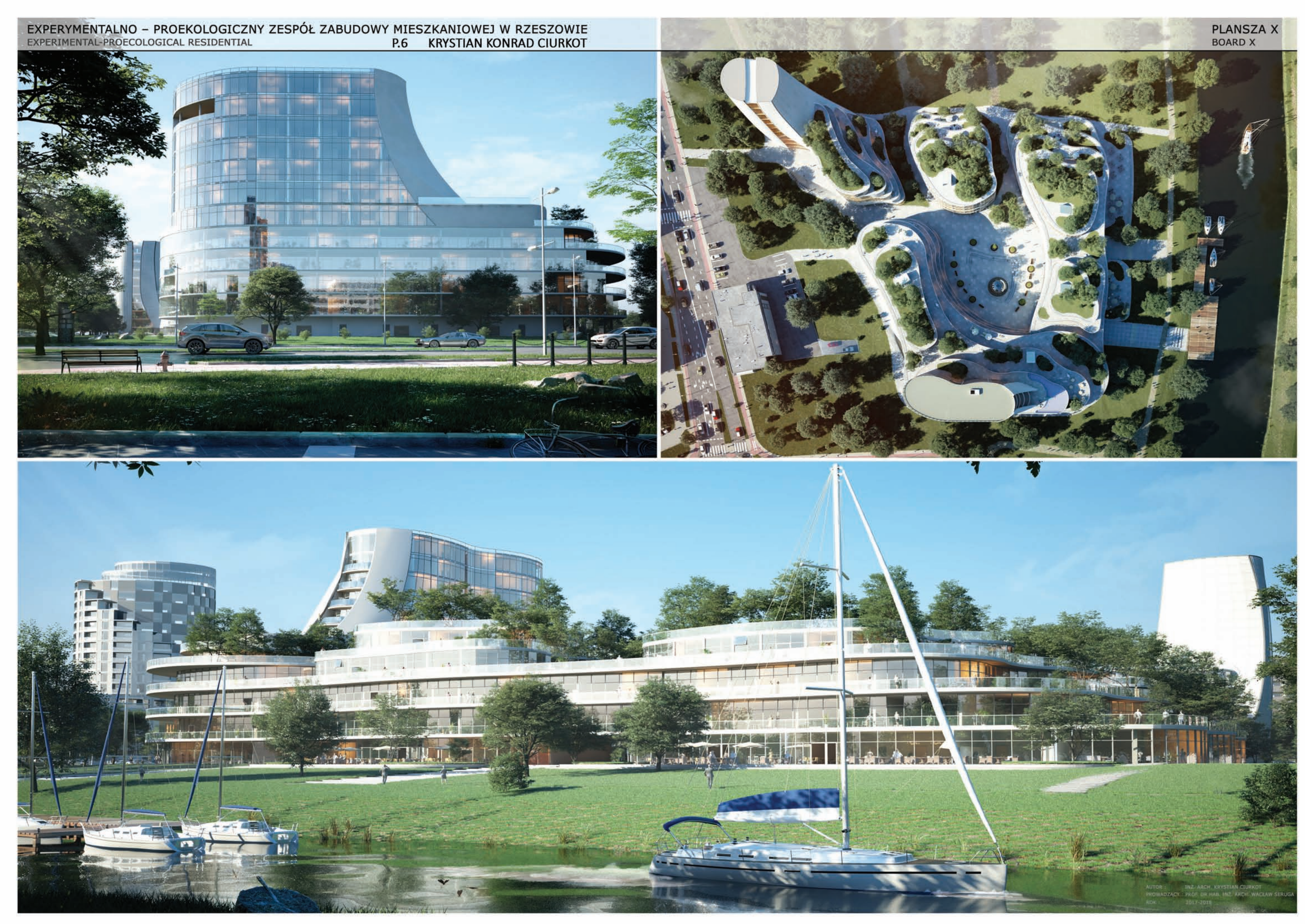




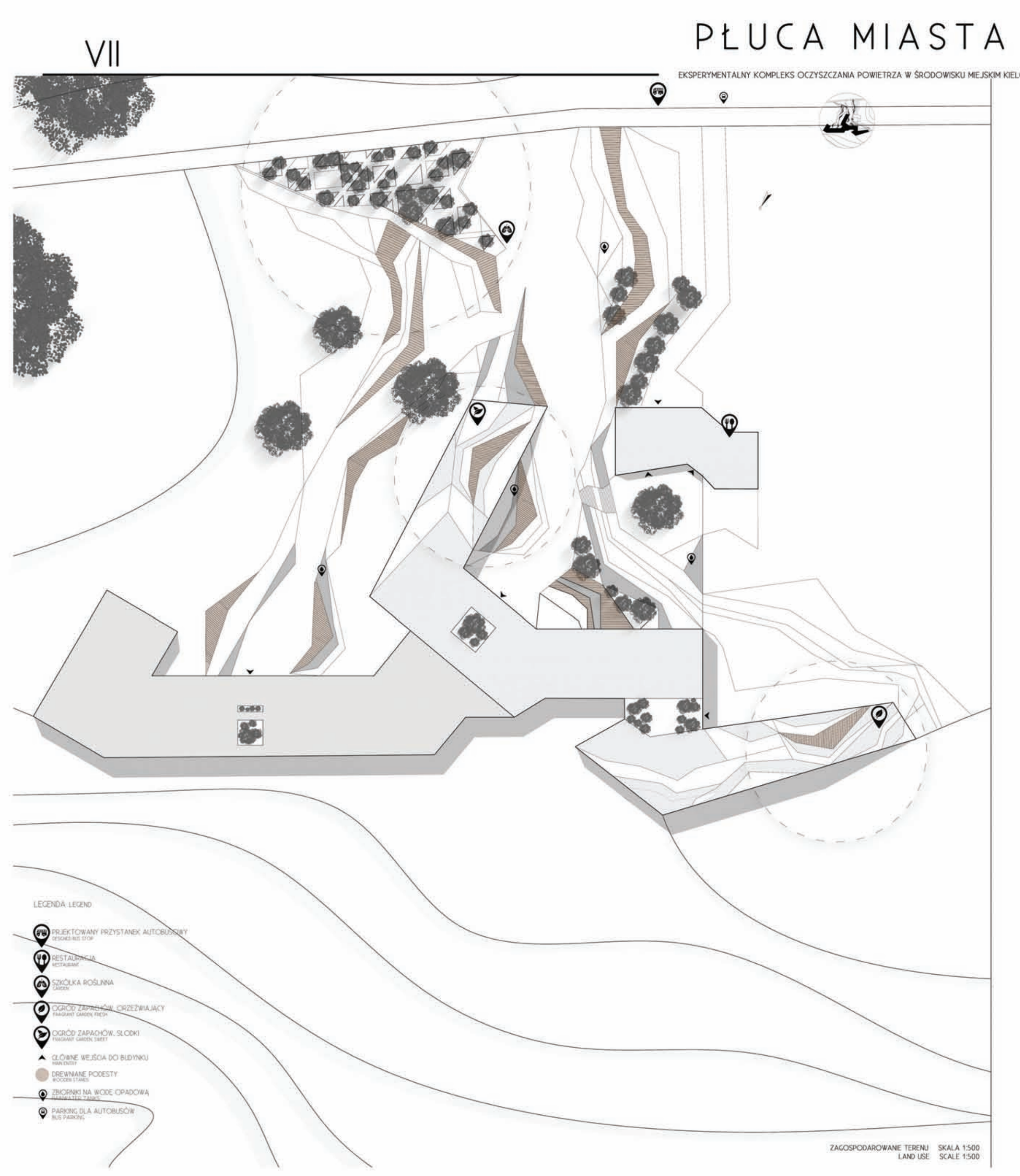

P.14 KAROLINA MET

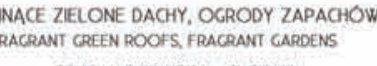

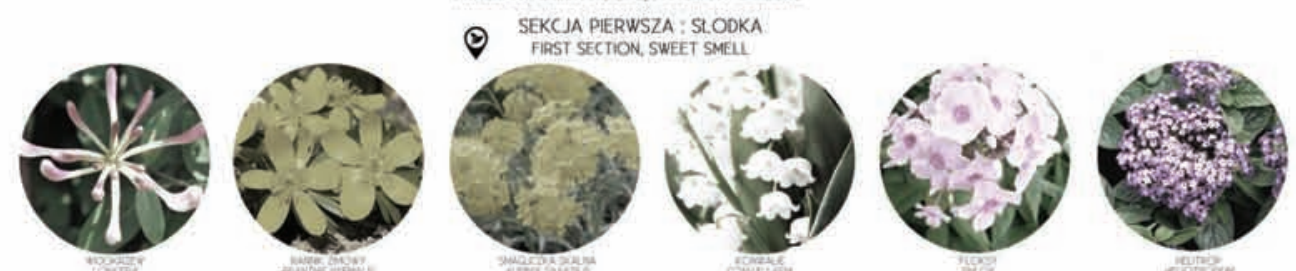

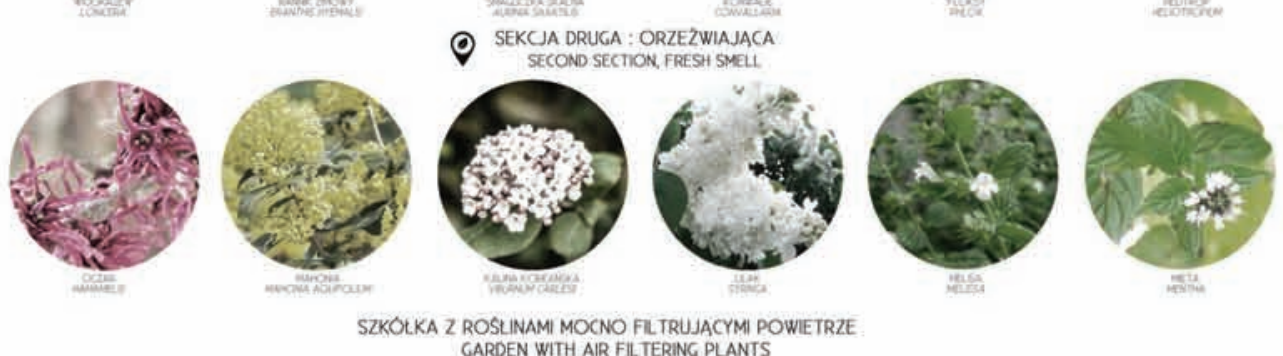

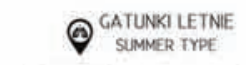

i. 1.4\%"

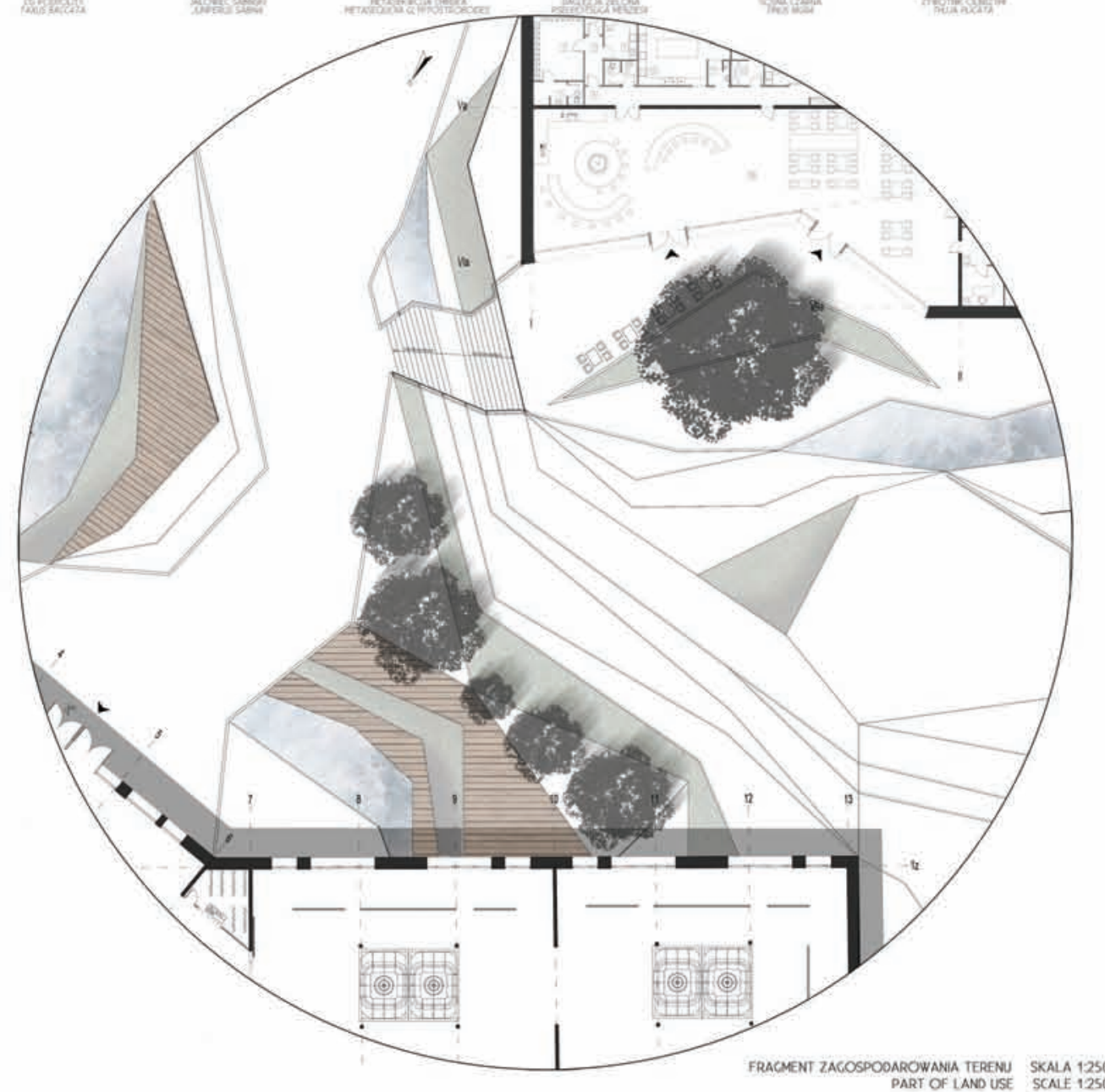




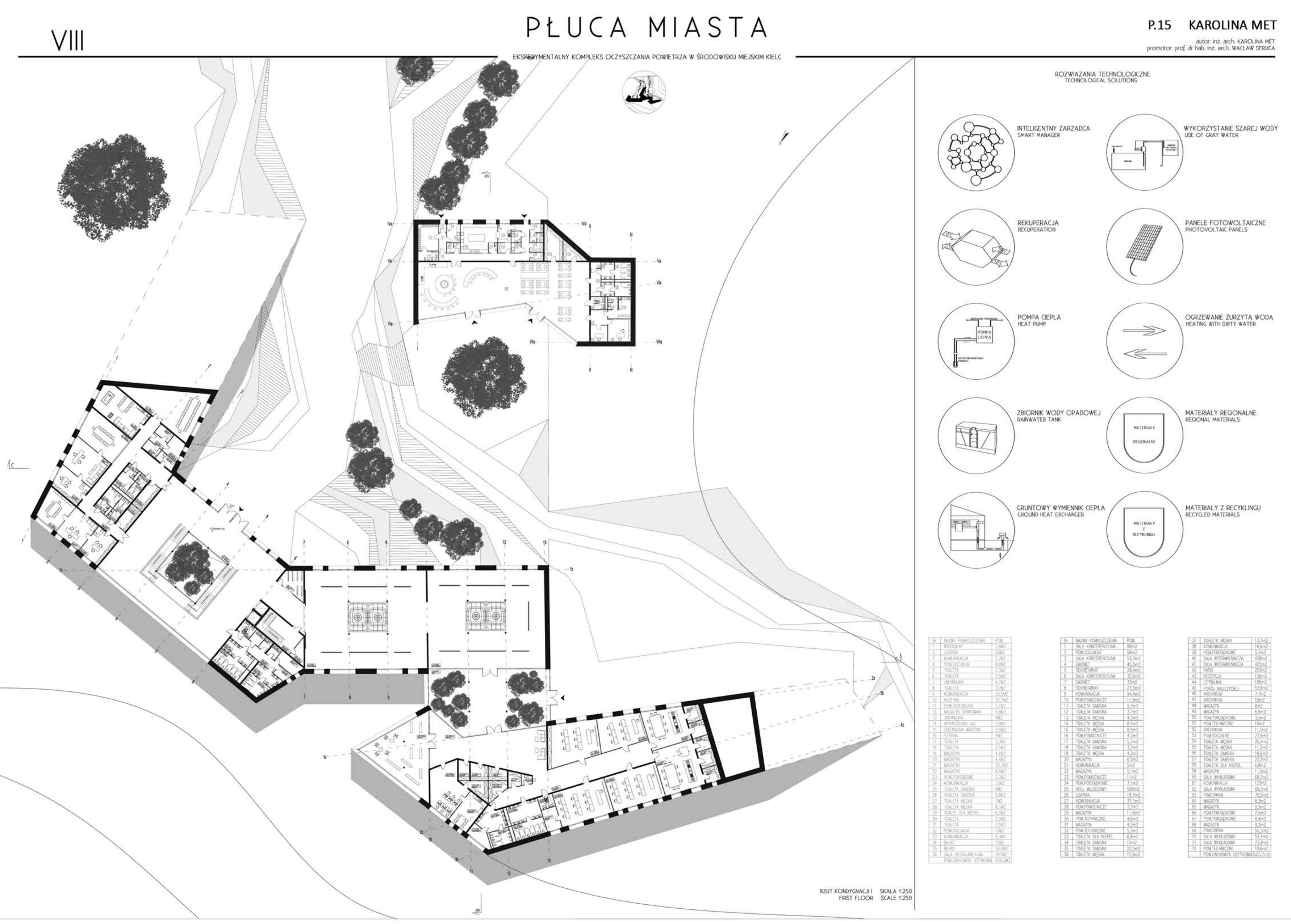



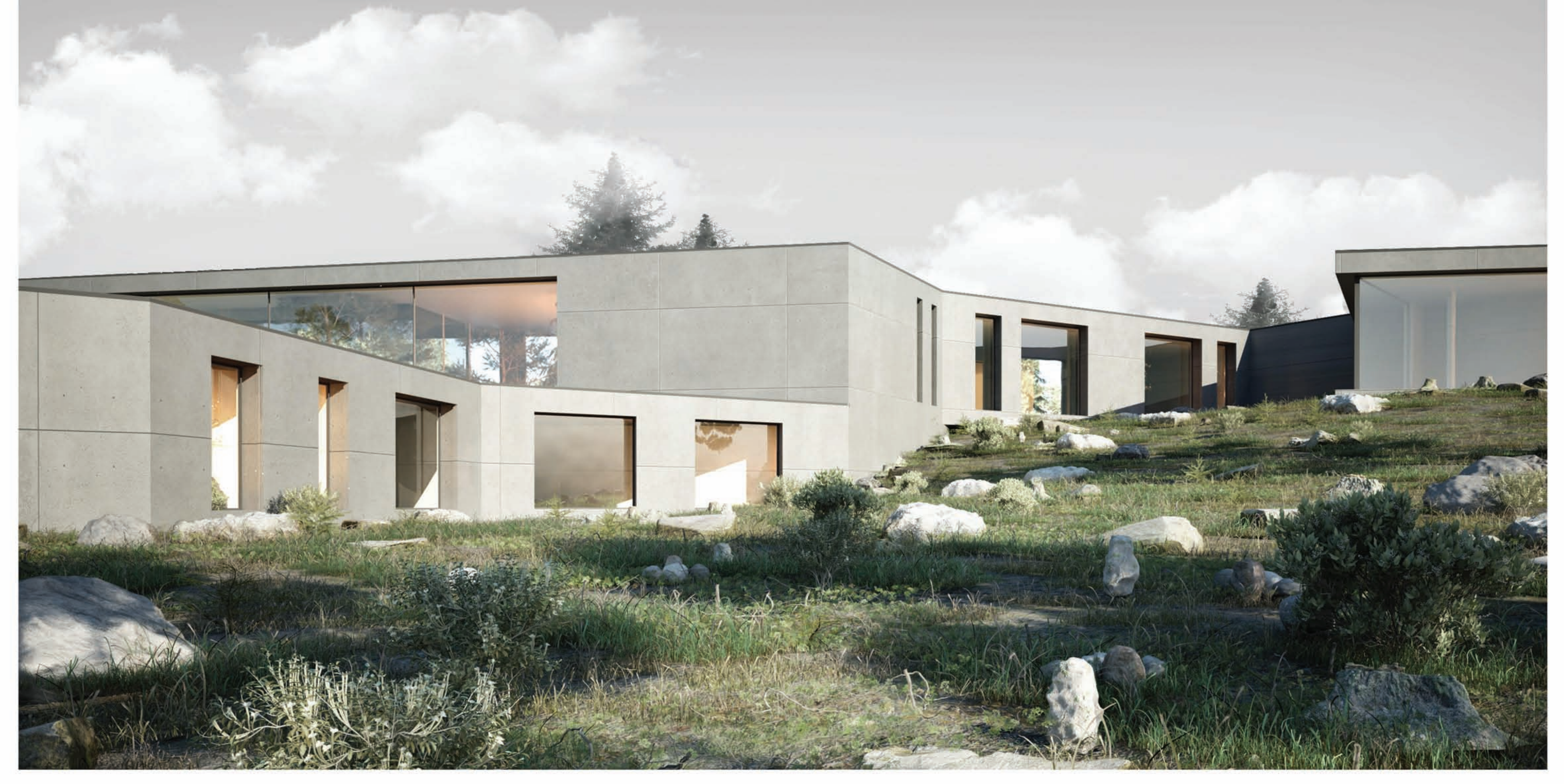


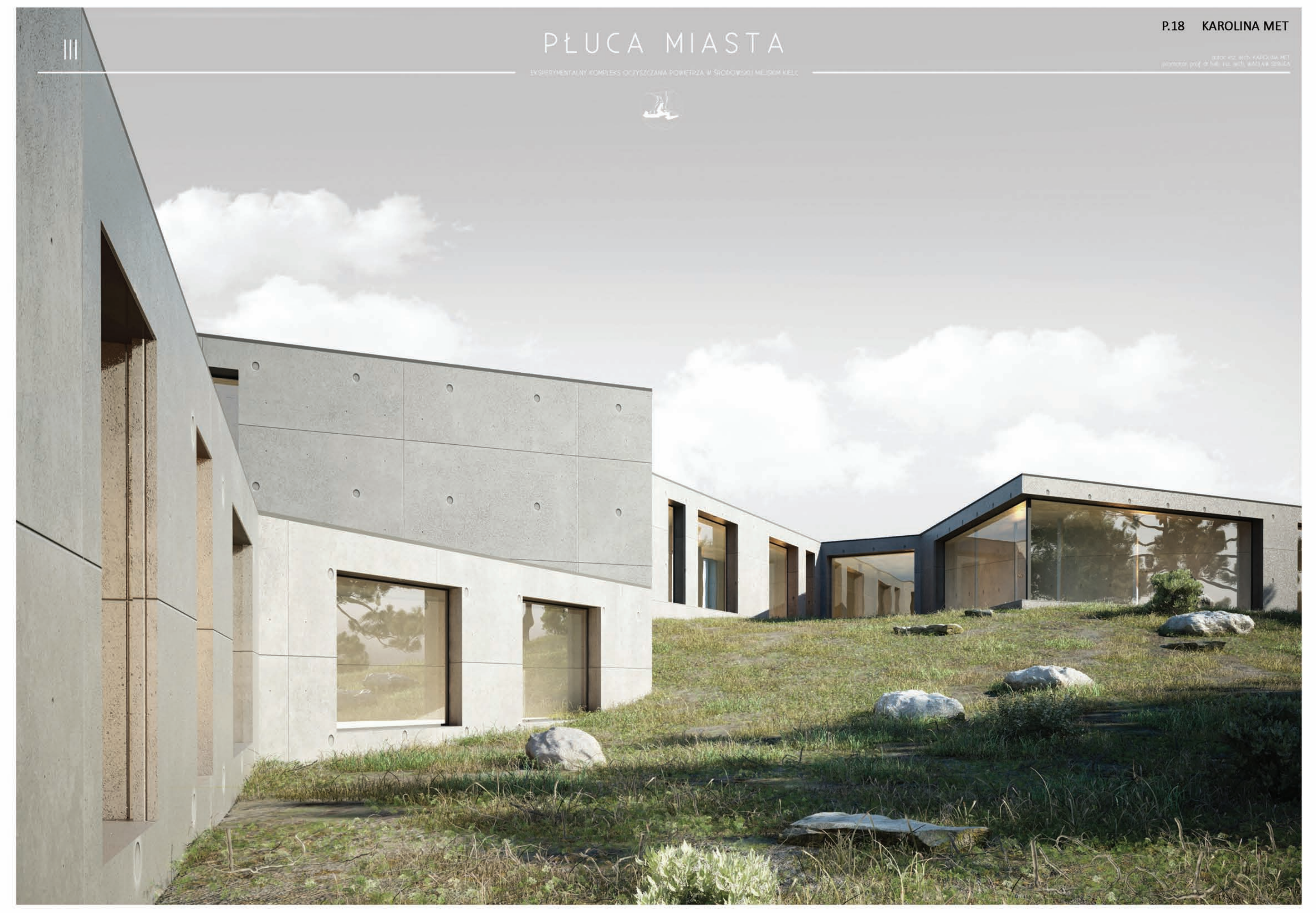




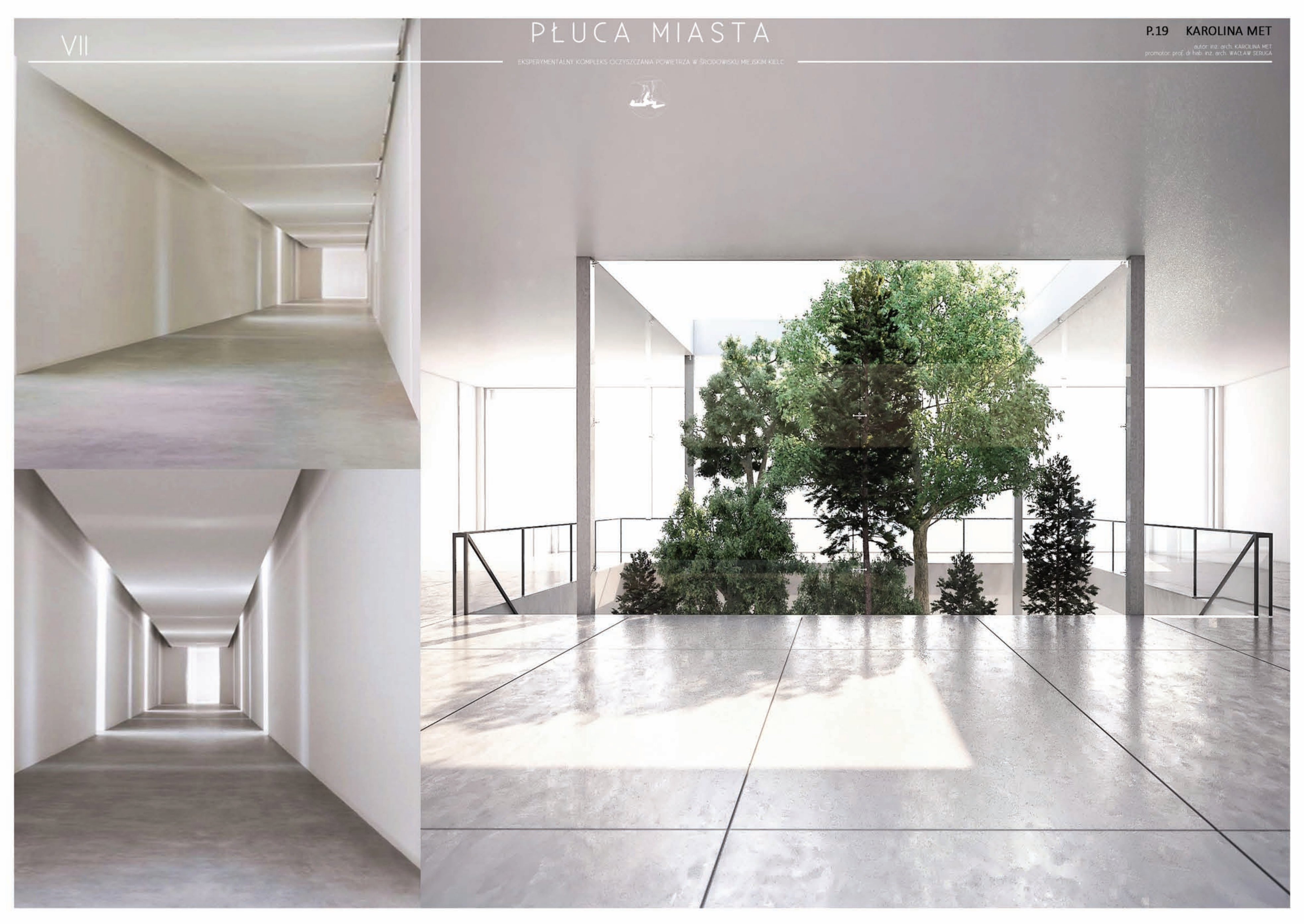




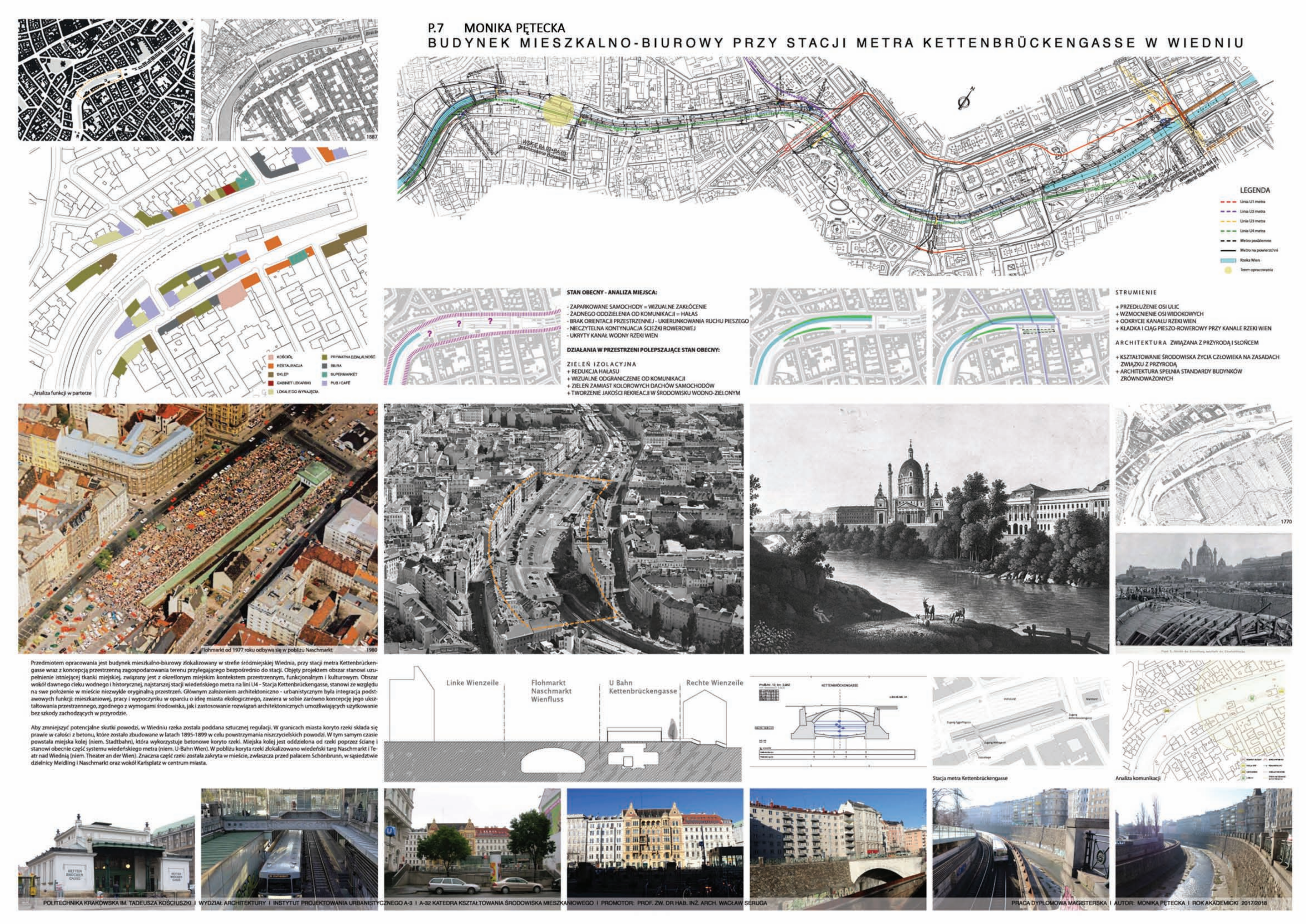




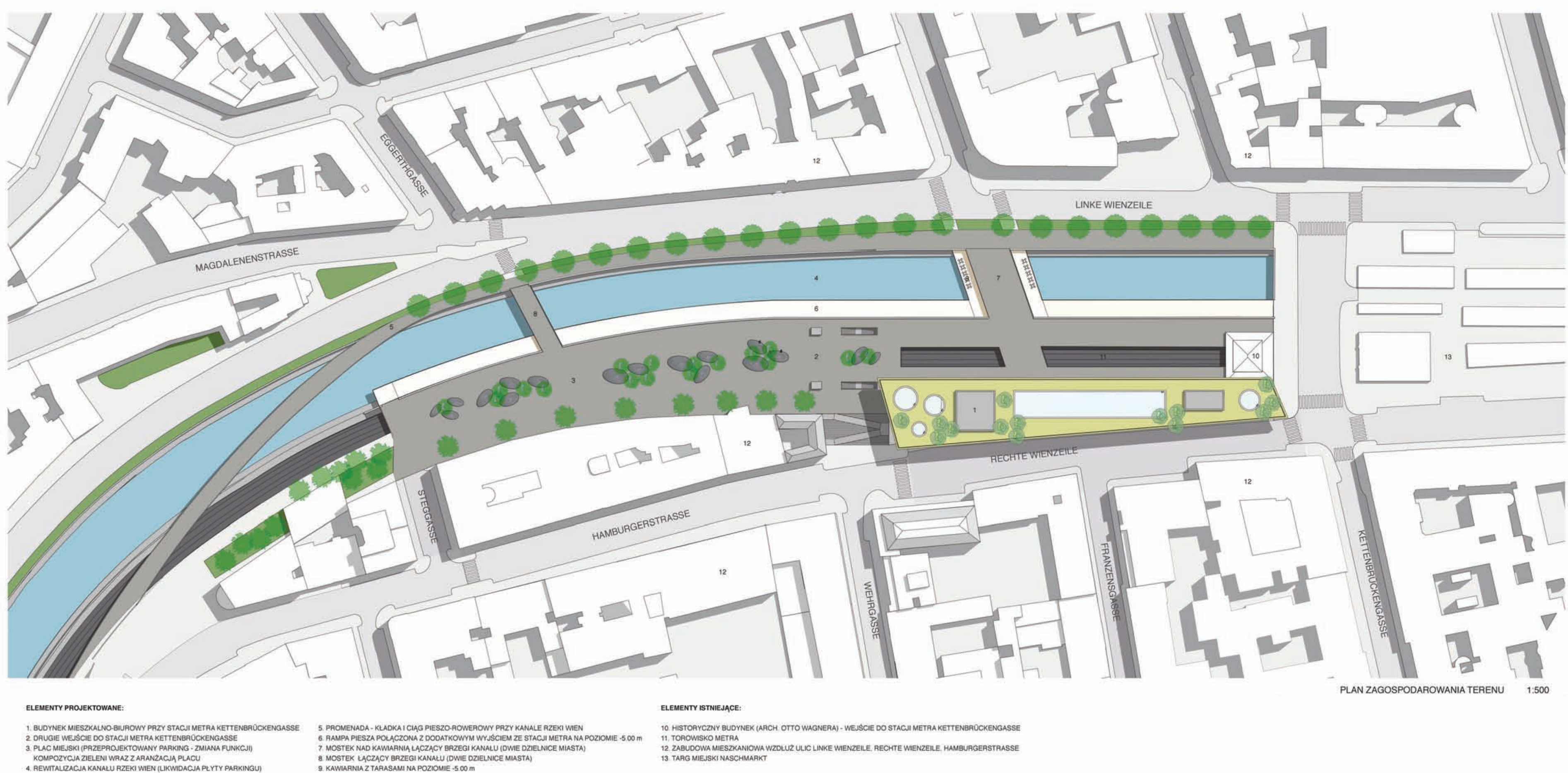

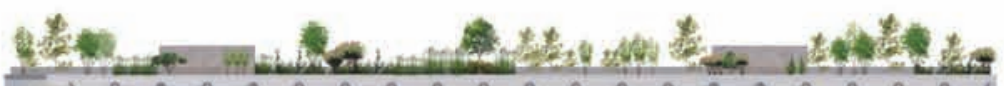

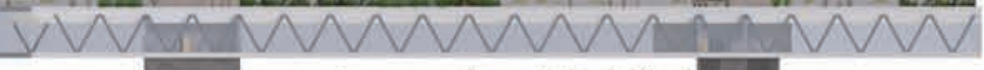

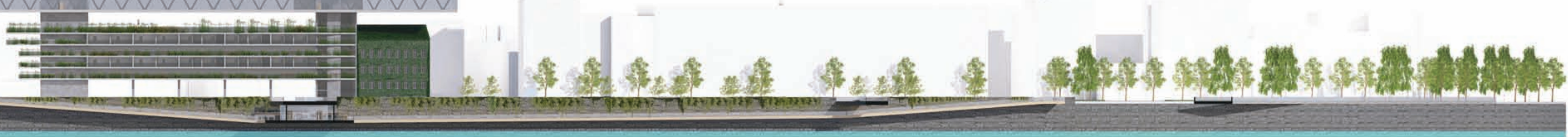



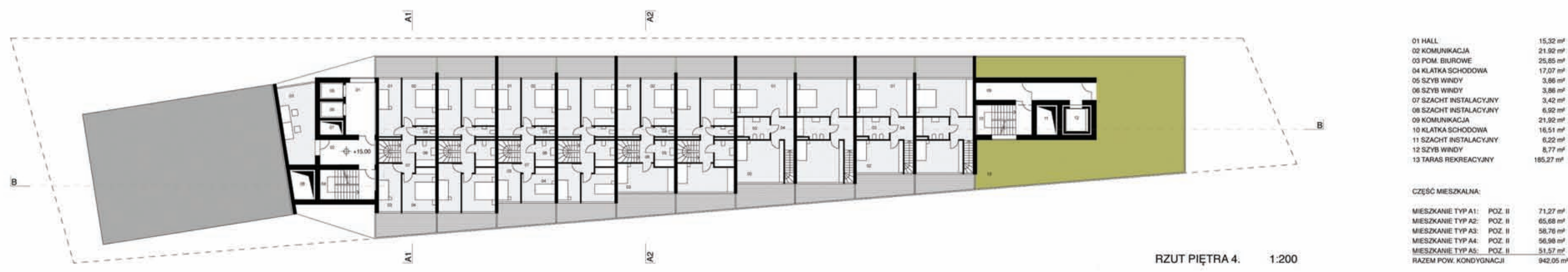

₹ृ a

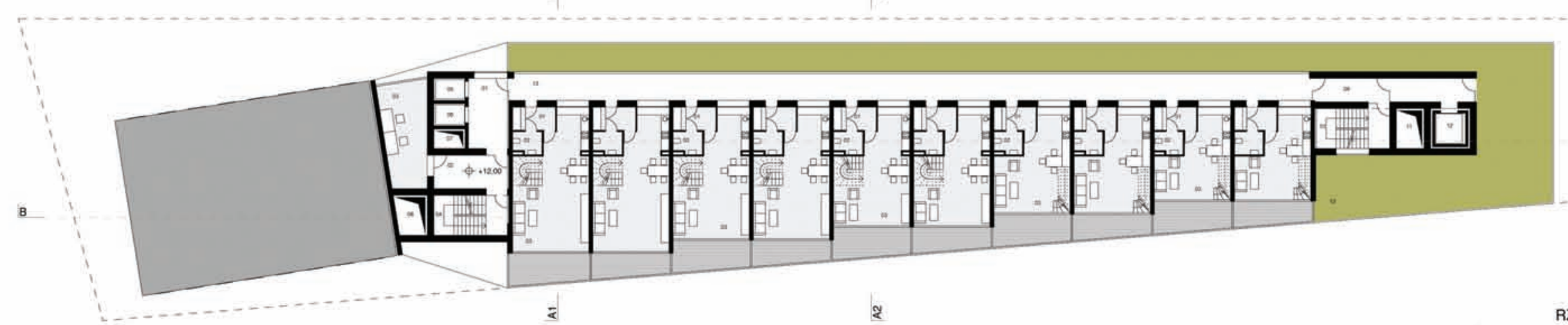

RZUT PIĘTRA $3 . \quad 1: 200$
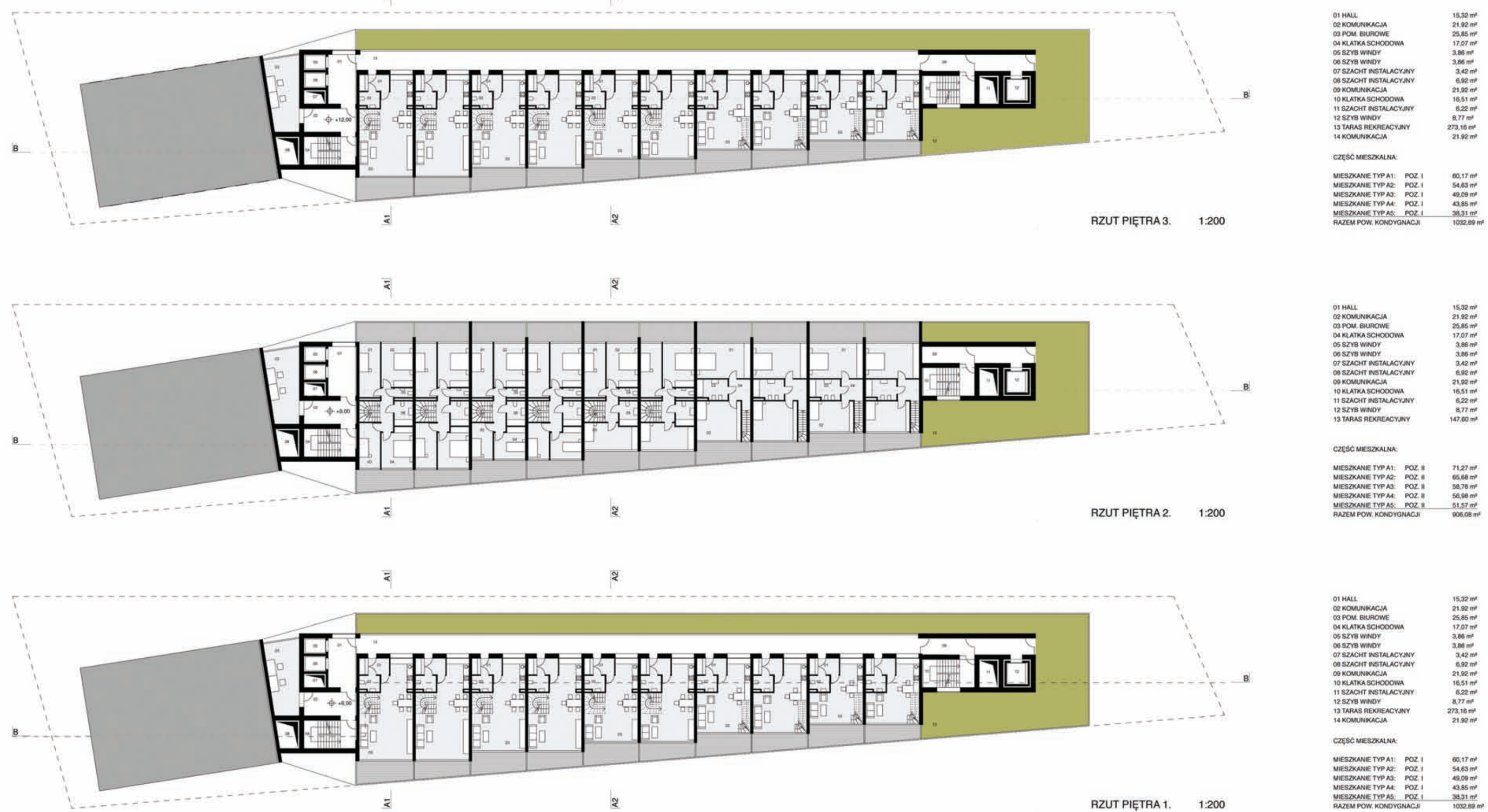

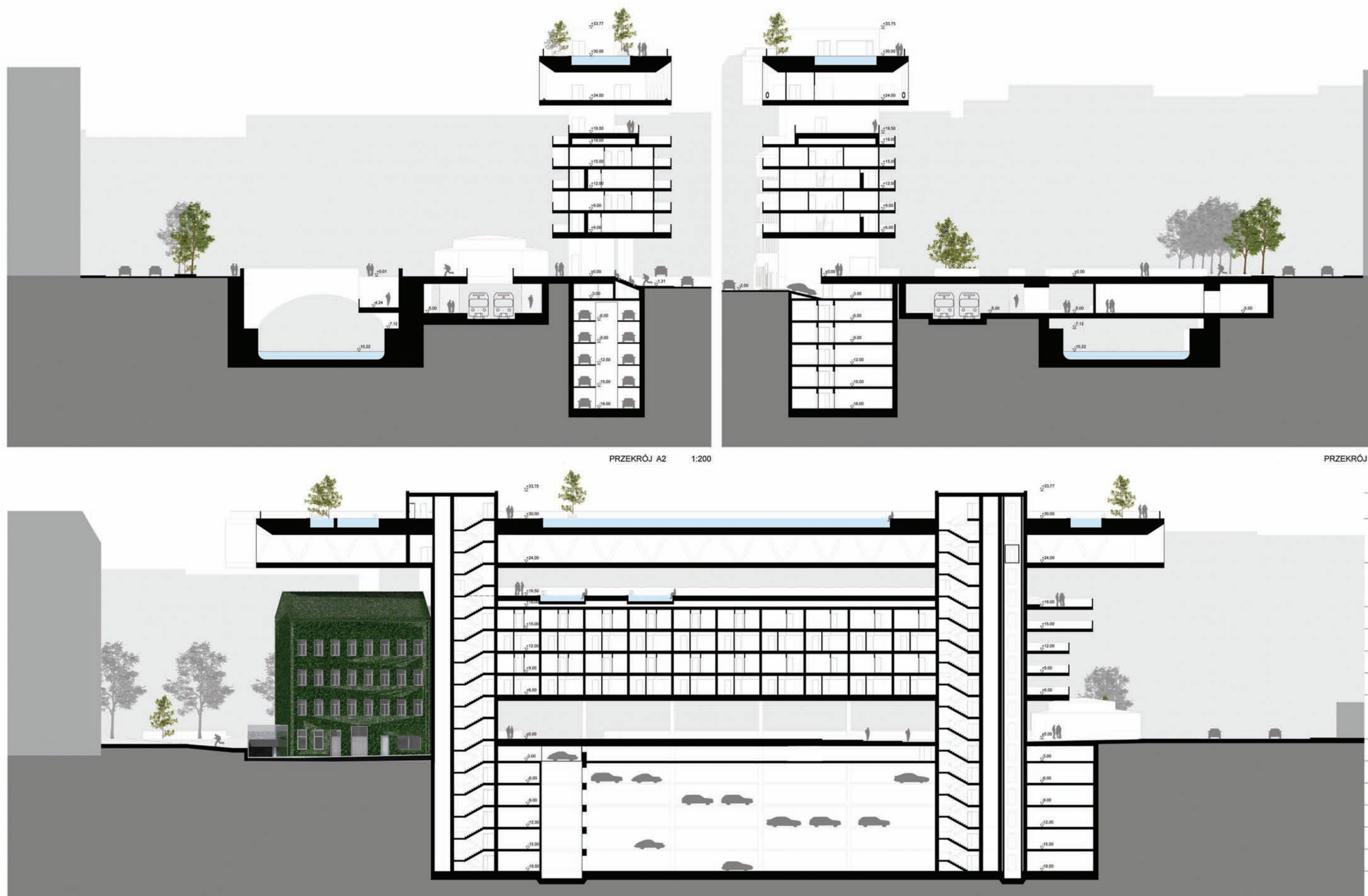

PRZEKROJ A2

1:200

PRZEKROJ A1 

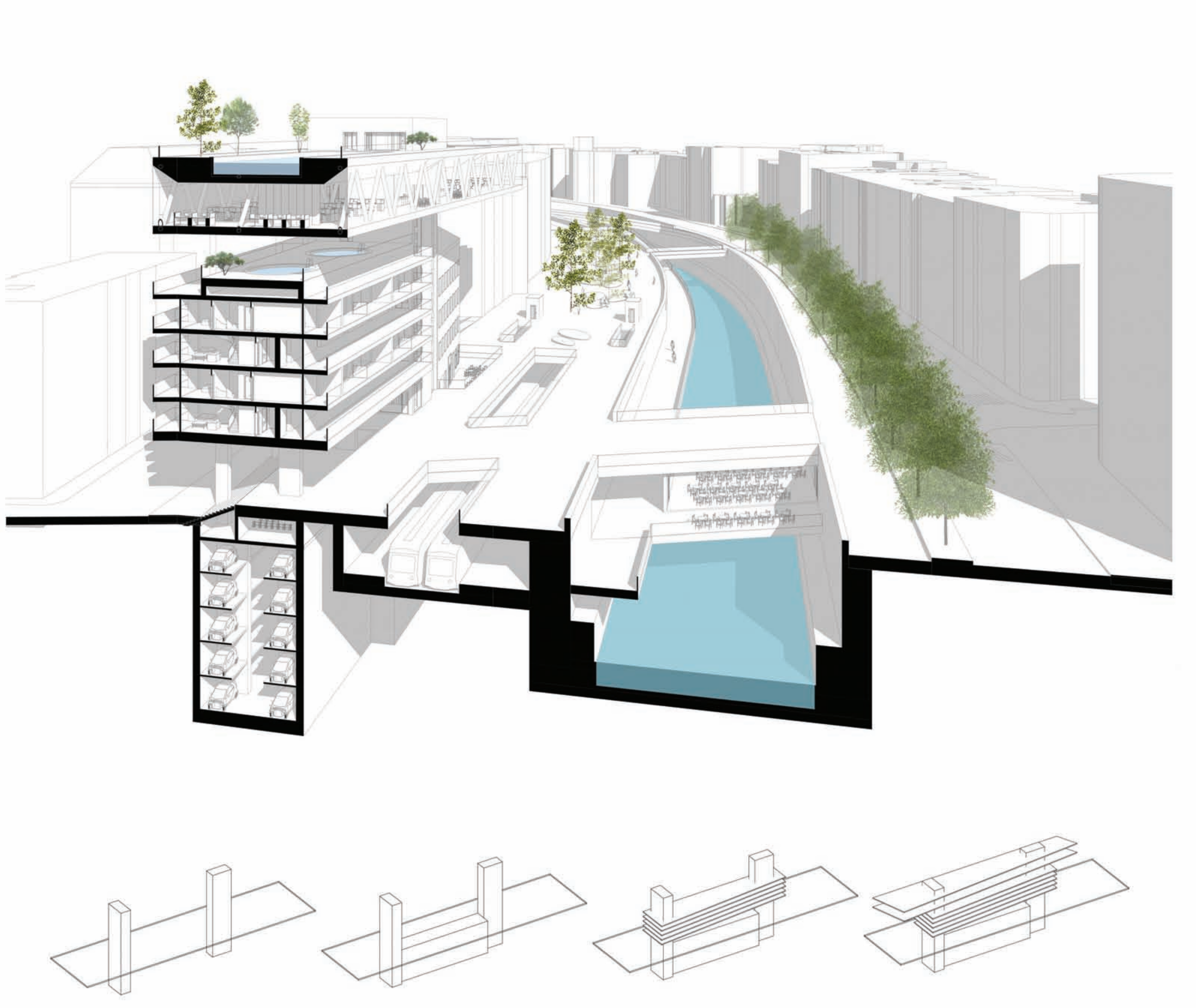

- - . - -

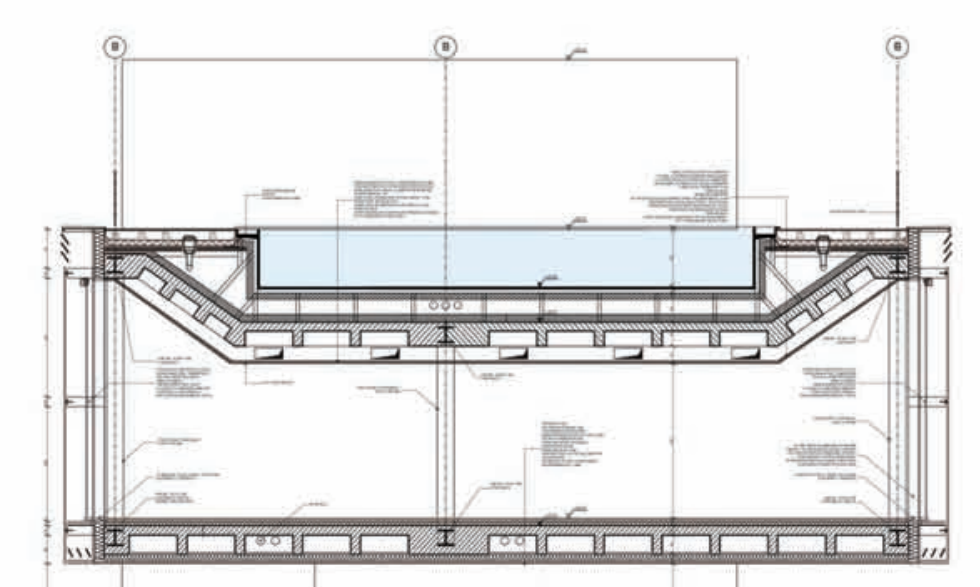

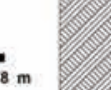

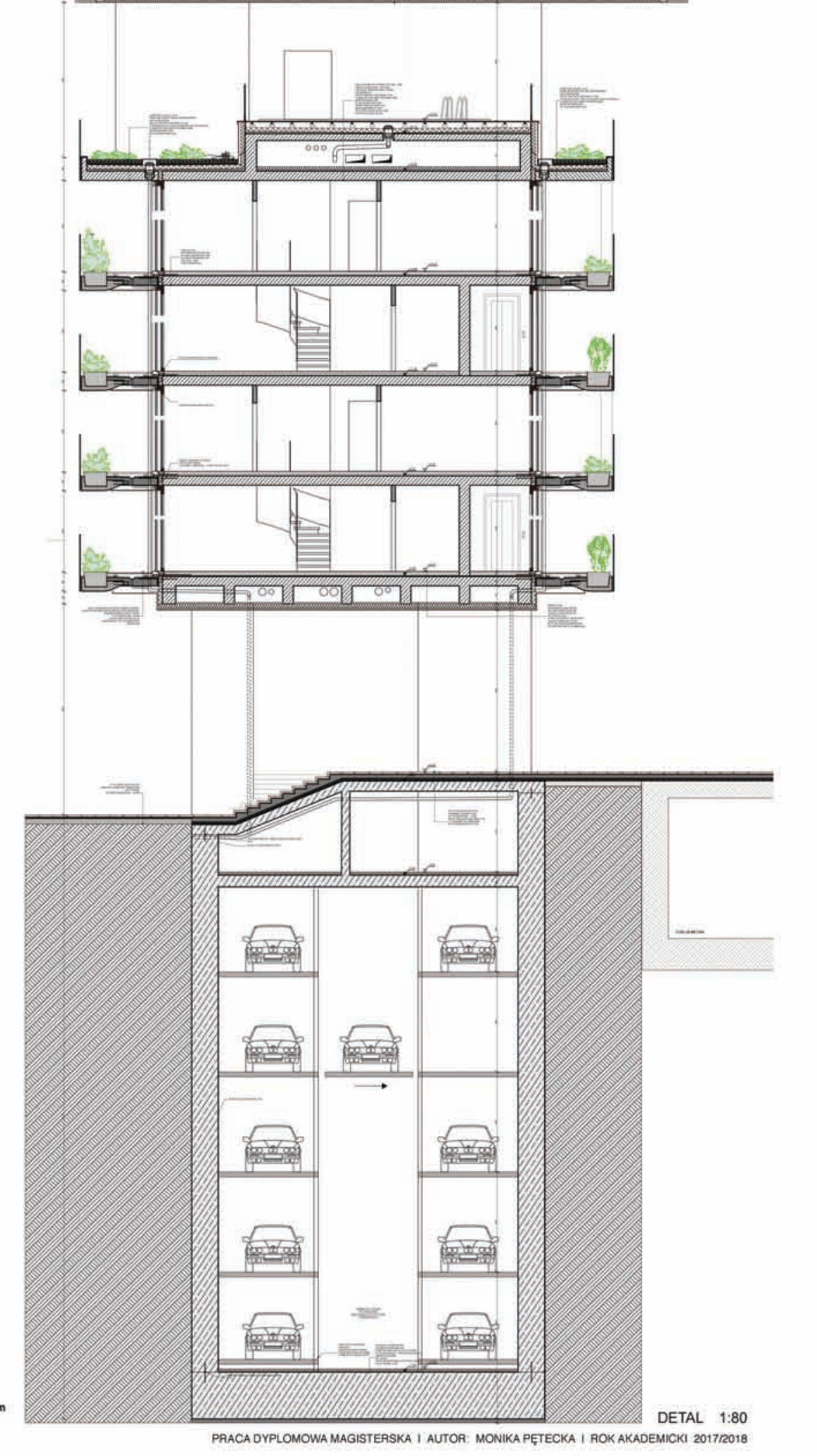


BUDYNEK MIESZKALNO-BIUROWY PRZY STACJI METRA KETTENBRÜC P.12 MONIKA PĘTECKA

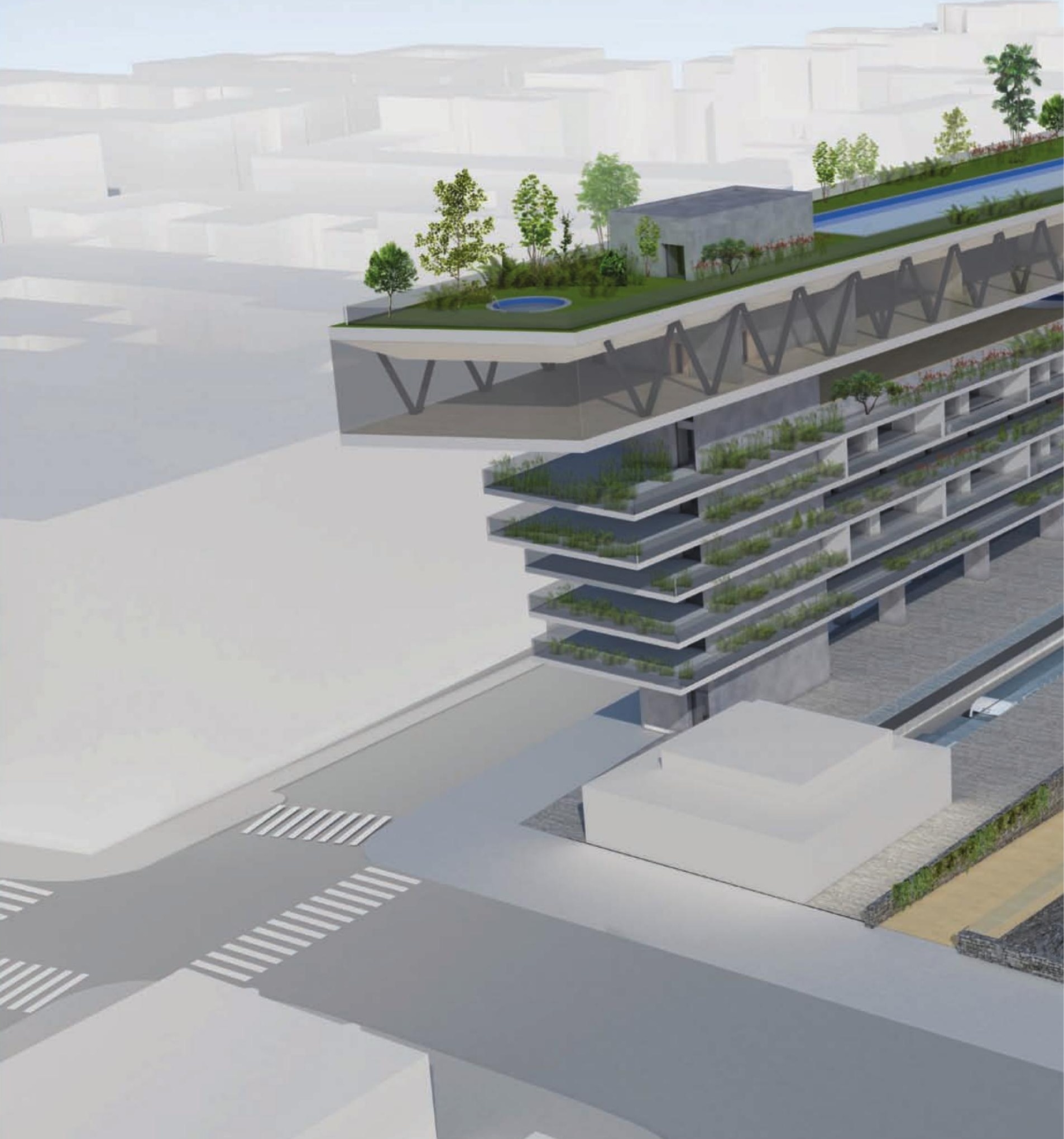

